AperTO - Archivio Istituzionale Open Access dell'Università di Torino

\title{
Extractive waste management: A risk analysis approach
}

\section{This is the author's manuscript}

Original Citation:

Availability:

This version is available http://hdl.handle.net/2318/1655781

since 2018-01-08T13:08:46Z

Published version:

DOI:10.1016/j.scitotenv.2017.11.260

Terms of use:

Open Access

Anyone can freely access the full text of works made available as "Open Access". Works made available under a Creative Commons license can be used according to the terms and conditions of said license. Use of all other works requires consent of the right holder (author or publisher) if not exempted from copyright protection by the applicable law. 
Extractive waste management: A risk analysis approach

Authors: Mehta, N., Dino, G.A.*, Ajmone-Marsan, F., Lasagna, M., Romè, C., De Luca, D.A.

*Corresponding Author

JOURNAL: Science of the Total Environment

EDITOR: Elsevier B.V.

VOL: 622-623,

PAGES: $900-912$

ISSN: 00489697

DOI: 10.1016/j.scitotenv.2017.11.260

SCOPUS ID: 2-s2.0-85037702819

WOS: NOT YET PRESENT

Printed: 1 May 2018,

On-line from December 2017 


\title{
$\underline{\text { Extractive waste management: A risk analysis approach }}$
}

\author{
Neha Mehta ${ }^{\mathrm{a}}$, Giovanna Antonella Dino ${ }^{\mathrm{a}}$, Franco Ajmone-Marsan ${ }^{\mathrm{b}}$, Manuela Lasagna ${ }^{\mathrm{a}}$, Chiara \\ Romè ${ }^{\mathrm{b}}$, Domenico Antonio De Luca ${ }^{\mathrm{a}}$ \\ ${ }^{a}$ Department of Earth Sciences, University of Torino, Via Valperga Caluso 35, 10125, Torino (Italy) \\ ${ }^{\mathrm{b}}$ Department of Agricultural, Forest and Food Sciences, University of Torino, Via Leonardo Da Vinci 44, 10095, \\ Grugliasco, Torino (Italy) \\ *Corresponding author's E-mail address: giovanna.dino@unito.it
}

\begin{abstract}
:
Abandoned mine sites continue to present serious environmental hazards because the heavy metals associated with extractive waste are continuously released into the environment, where they threaten human life and the environment. Remediating and securing extractive waste are complex, lengthy and costly processes. Thus, in most European countries, a site is considered for intervention when it poses a risk to human health and the surrounding environment. As a consequence, risk analysis presents a viable decisional approach towards the management of extractive waste.

To evaluate the effects posed by extractive waste to human health and groundwater, a risk analysis approach was used for an abandoned nickel extraction site in Campello Monti in North Italy. This site is located in the Southern Italian Alps. The area consists of large and voluminous mafic rocks intruded by mantle peridotite. The mining activities in this area have generated extractive waste.

A risk analysis of the site was performed using Risk Based Corrective Action (RBCA) guidelines, considering the properties of extractive waste and water for the properties of environmental matrices. The results showed the presence of carcinogenic risk due to arsenic and risks to groundwater due to nickel. The results of the risk analysis form a basic understanding of the current situation at the site, which is affected by extractive waste.
\end{abstract}

Keywords: risk analysis, mining waste, environmental impacts, extractive waste, abandoned mine, reuse

\section{Introduction}

Mining waste, which is also referred to as extractive waste (EW) generated during mining activities for metal exploitation, is represented by huge amounts of materials that are often contaminated by heavy metals and toxins and stored in dumps near the mining sites. After the cessation of mining activities at many sites, the EW facilities were left abandoned, leaving large amounts of waste subjected to erosion and leaching. Climate conditions, topography, hydrology, soil and EW textures, vegetation and site management influence the dispersion of contaminants towards adjacent ecosystems. Due to this dispersion and erosion, high contents of heavy metals have often been reported in ecosystem compartments near metal extraction sites (Béjaoui et al., 2016, Balint et al., 2014, Balint et al., 2015). These heavy metals tend to persist in the environment due to their nondegradable characteristics (Yuan et al., 2004). To measure their environmental impacts and determine future courses of action for the sustainable management of extractive waste, risk analysis approaches can be used.

The use of risk analysis as a formal component of environmental policy is of relatively recent origin. An original aim of this methodology was to help set priorities for environmental protection in an objective and scientific way, thus avoiding conflicts with political and management objectives. In simple terms, risk analysis can be defined as the process of estimating both the probability that an event will occur and the probable magnitude of its adverse effects, whether health/safety-related or ecological, over a specified time period (Gerba, 2009). 
Many previous studies have provided methods for using heavy metal distributions and risk analysis in the context of the effects of mining activities on environmental and human health ( $\mathrm{Li}$ and Thornton, 2001, Väänänen et al., 2016). For example, soil pollution due to lead, zinc, cadmium and copper has been characterized in mine tailings and soil near a $\mathrm{Pb}-\mathrm{Zn}$ mine in Spain (Rodríguez et al., 2009). The presence of $\mathrm{Ni}$ and $\mathrm{Cr}$ has been quantified in open cast coal mining areas in Serbia (Ličina et al., 2017). Another study assessed human health hazards arising from the consumption of fish contaminated by mercury released in gold mining areas in Indonesia (Castilhos et al., 2006). The quantification of human health risks due to soil contamination in mining areas in China was studied by Li et al., 2014. The results obtained from these studies provide an important basis for the quantification and management of environmental impacts at mining sites.

The present study addresses an abandoned Ni mining site at Campello Monti in northwest Italy and differs from past studies by also focusing on a comparative analysis due to a change in the location of the EW. Indeed, this work was undertaken to analyse the risk in Campello Monti due to the presence of EW to 1) human health and groundwater in the present situation and 2) human health and groundwater under the hypothesis that the waste is transported to the nearest plain and used, as a by-product, for land rehabilitation or as filling materials for civil works and infrastructures. The second case has to be considered as an alternative to in situ intervention activities; using the waste as a resource is a viable alternative to remediating polluted areas and contemporaneously boosting natural resource savings. The principle of recovering and using waste (with or without treatment) as valuable secondary raw materials for integration with raw materials (RM and critical raw material $\mathrm{CRM}$ ) is in line with present EU policy regarding landfill mining and circular economies (Dino et al. 2016, 2017,a). Indeed, securing a sustainable RM and CRM supply and their circular use in the economy is a growing matter of concern at both EU and global levels (Coulomb et al., 2015; VidalLegaz et al. 2016). A circular approach can partially supply RM/CRM due to the prominent role of recycling/recovery as an alternative to the exploitation of ore-bodies. Indeed, the recycling rates for each RM (and CRM) are useful for calculating the supply risks connected to single commodities (Blengini et al., 2017). In particular, the integration of extractive waste with natural aggregate supplies is being increasingly realized, and several researchers have investigated opportunities for sustainable recovery and recycling of both clean and contaminated EW, while at the same time reducing pressure on natural aggregate resources, land takes and environmental and landscape contamination. All this entails a general recovery of land, raw materials and eventually the environment (Akbulut and Gürer, 2007; Binici et al., 2008, Careddu et al. 2013; Danielsen and Kuznetsova, 2015; Danielsen et al. 2017; Dino et al. 2017,b; Dino and Marian, 2015; Felekoglu, 2017, Hebhoub, 2011; Gencel et al., 2012; Luodes et al. 2012).

\section{Methodology}

\subsection{General Site Setting}

An abandoned Ni mine at Campello Monti was chosen for the present study. The Campello Monti site lies on the boundary of the Valstrona municipality in NW Piemonte (Italy) (45 $56^{\circ} 09.39$ " N and $8^{\circ} 14^{\prime} 13.79$ ” E), as shown in Fig 1. The site is located in the Strona Valley, which is oriented WSWENE and lies to the east of Monte Rosa. The valley is confined by the Anzasca Valley to the NW, the Ossola Valley to the E-NE, and the Sesia Valley to the S-SE.

The Campello Monti village is located on the valley floor at $1305 \mathrm{~m}$ a.s.1. The Strona Valley reaches its maximum altitude at the terminal sector, which is bordered by the Capezzone Mount (2421 m a.s.1.) and the Altemberg Mount (2394 m a.s.1.). 
The extractive waste facilities are mainly located in the north side of the valley, from the eastern margin of the Campello Monti village to approximately $1 \mathrm{~km}$ eastward at altitudes ranging from ca. 1200 to $1600 \mathrm{~m}$ a.s.1.

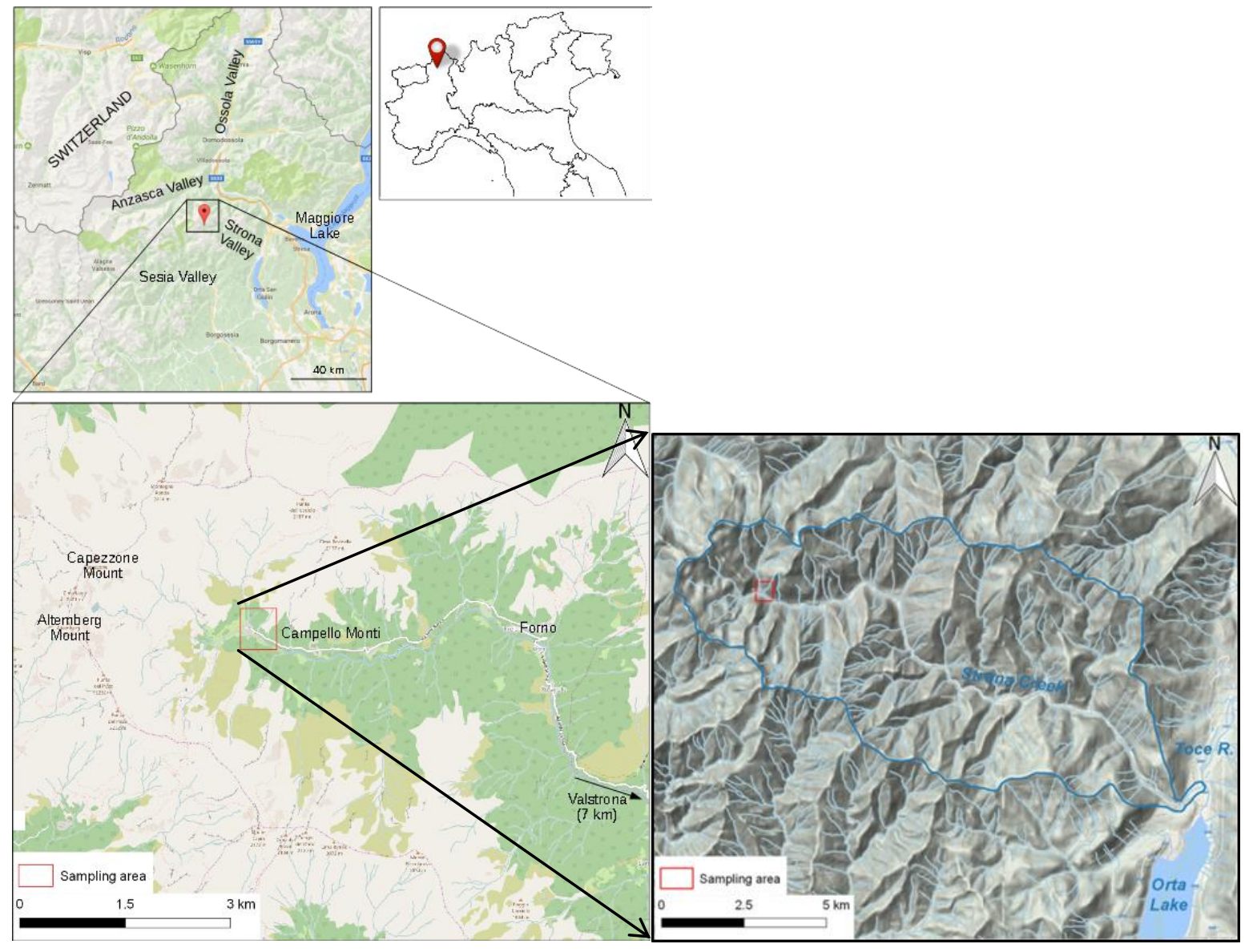

Fig. 1. Geographical location of Campello Monti.

\subsubsection{Geological Setting}

A metal extraction site is located in the basement of the southern Alps of northwestern Italy in the Ivrea Verbano Zone, which is a tectonic unit that has been cited as an example of an exposed continental crustal section that has preserved the transition from amphibolite to granulite facies (Bea and Montero, 1999). The Ivrea Verbano Zone extends for a distance of $120 \mathrm{~km}$ and has a breadth of approximately $14 \mathrm{~km}$ (NW-SE direction). The Ivrea Verbano Zone consists of three main petrographic units (Garuti et al., 2001):

- ultramafic rocks known as Mantle Tectonites,

- mafic rocks of the Mafic complex;

- $\quad$ supracrustal rocks of the Kinzigite Formation.

This area consists of large and voluminous mafic rocks that belong to the mafic complex outcrop, which is intruded by the mantle peridotites of the Mantle Tectonites (Fig. 2). At the western border of the area, the Insubric Line borders the Alpine units of the Sesia Lanzo Zone. On the valley floor, the bedrock is buried by recent glacial deposits and alluvial debris. 
The detailed lithology of the area (Fig. 2) consists of lherzolites that are accompanied in places by titanolivine in large and smaller masses. In the surrounding regions, on the upstream side of the valley, mylonites are found along the Insubric Line, which are followed by phyllites and schists of the Alpine units. In the downstream sector of the valley, alternations of metabasites and metapelites prevail.

The area was exploited for Fe-Ni-Cu-Co magmatic sulphide deposits that occur from the Sesia to Strona valleys, primarily in the ultramafic layers of the mafic complex of the Ivrea Verbano Zone. Nickel extraction from the ore occurred intensively from 1863 to the 1940s (Rossetti et al., 2017).

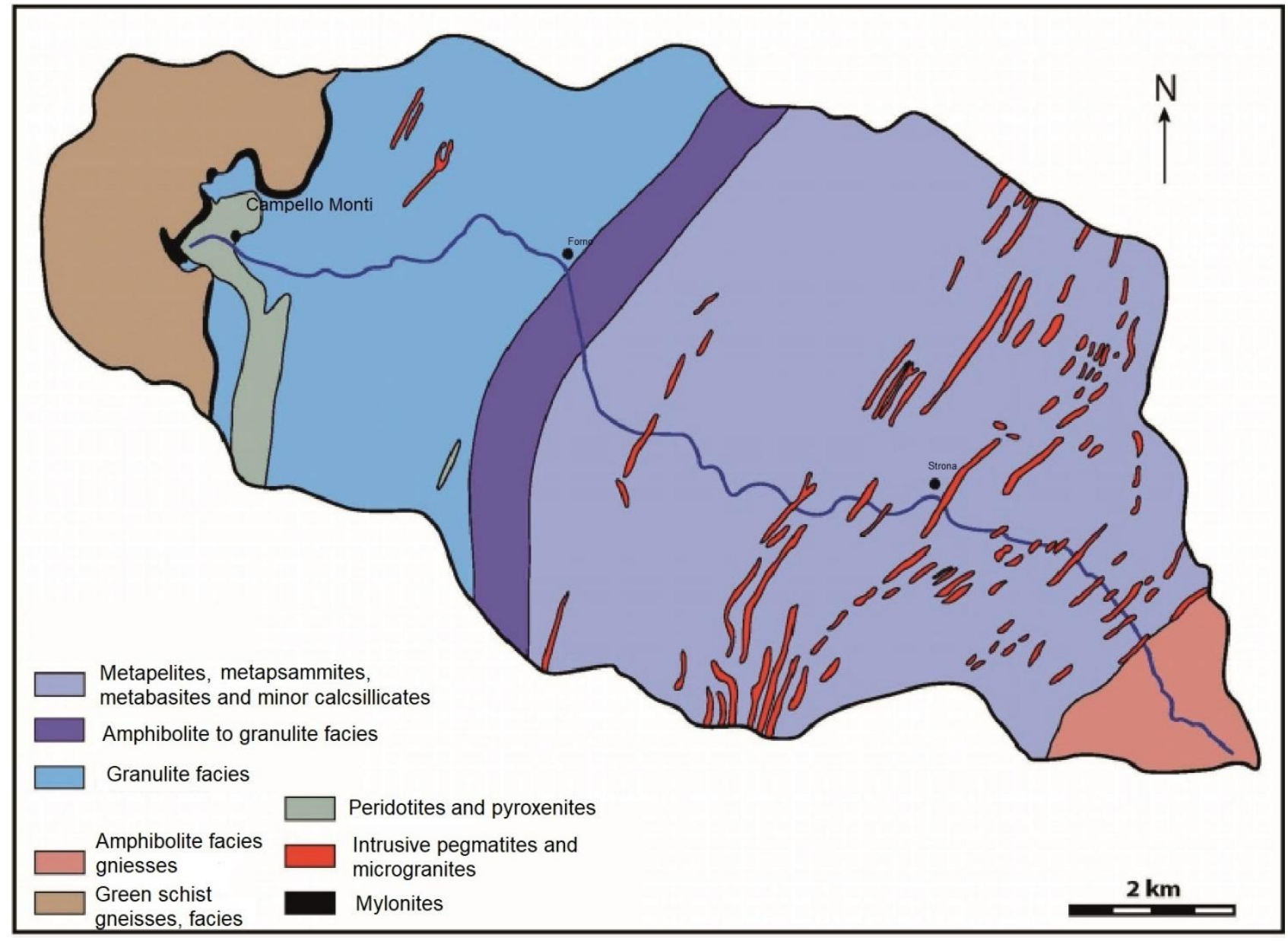

Fig. 2. Simplified lithological map of Val Strona of Omegna (modified from Bea and Montero, 1999).

\subsubsection{Hydrography}

The Strona stream (also known as the Strona di Omegna stream) is the main stream of the Strona Valley and flows in a WNW-ESE direction (Fig. 1). It is fed by runoff, snow-melt springs and small lakes located in the surrounding relief. The Strona stream begins in the village of Campello Monti and ends in the Toce river, and its total length is approximately $28 \mathrm{~km}$. The hydrographic basin of the Strona stream has an area of approximately $170 \mathrm{~km}^{2}$ (Fig. 1). The final destination of the waters of the Toce River is Lake Orta, which is located a few hundred metres from the confluence of the two streams towards the south. 


\subsubsection{Hydrogeological setting}

Campello Monti is located in extremely complex formations of crystalline rocks that consist of metamorphic lithotypes. According to the regional hydrogeological framework, these rocks are essentially impermeable or weakly permeable for fracturing and belong to the hydrogeological series of crystalline complexes of the Alpine chain. A conceptual scheme of groundwater flow in the area is represented in Fig. 3, which shows that groundwater circulation in the area occurs in fractured rocks, detritic cover, waste dumps and tunnels used for extracting metal.

The groundwater flow through detritic cover and waste dumps was considered to be predominant. The groundwater flow in the natural rocks at the site is very low because they are compact metamorphic rocks with reduced levels of fracturing. Indeed, the groundwater drainage in the tunnels shows very low or no discharge. Thus, for the risk analysis, only groundwater in detritic cover and waste dumps was considered, and the proposed flow regime is suitable for use in the risk modelling approach.

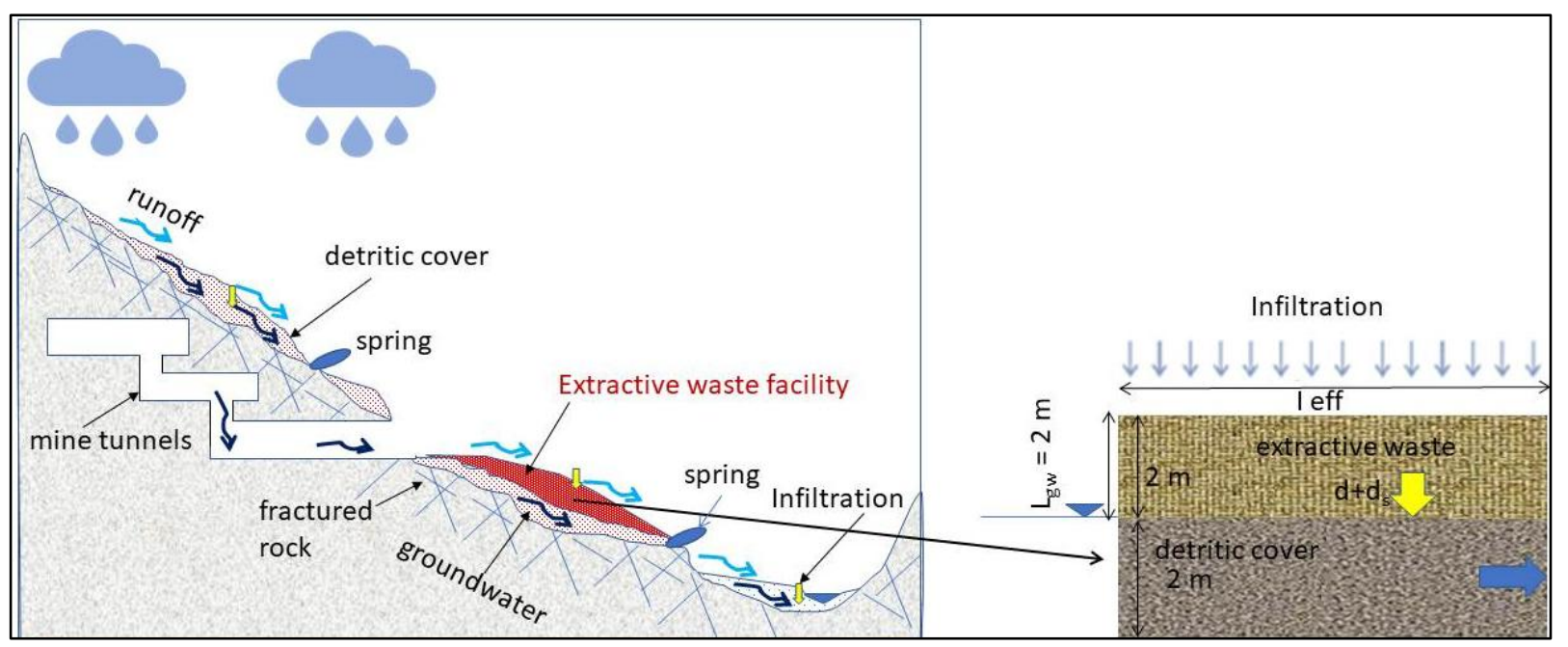

Fig. 3. Conceptual scheme of the groundwater flow at the site.

\subsection{Site investigation and sampling strategy}

\subsubsection{Sampling of extractive waste}

The sampling activity comprised preliminary site investigation and preparation of samples for the characterization.

The preliminary site investigation was performed to collect information regarding waste typology and location in order to ensure that the facility was suitable for characterization and sampling. The sampling site comprised different waste rock piles. These waste rock dumps were placed in the north side of the Strona stream and have not been moved or worked since the end of mining activity. The dumps were formed over a period of approximately 100 years by the dumping, in a vertical sequence, of non-valuable mineralizations and non-mineralised rocks from underground extraction activities. The waste rock dumps are unconfined in nature, which has led to a fairly similar distribution of EW in the area. The average thickness of the cover formed by the EW was found to be approximately $2 \mathrm{~m}$. Field observations have demonstrated the presence of both fine and coarse materials. 
Locations and numbers of sampling points are often site-specific, but in general, a systematic sampling strategy must be adopted in order to obtain representative data for an entire waste facility. In the Campello Monti area, the waste rock material was sampled using a hand shovel and hammer (where necessary). Each sample $\left(8-10 \mathrm{~kg}\right.$ ) was collected in an area of $1.5 \mathrm{~m}^{2}$, after which the samples were cleaned to remove organic residues. Fig. 4 shows sampling methodology. A total of 26 waste rock samples were collected at the site in July 2016. The sample locations are shown in Fig. 5.

Preparation of waste rock samples for characterization is reported in analytical methods section (section 2.3).
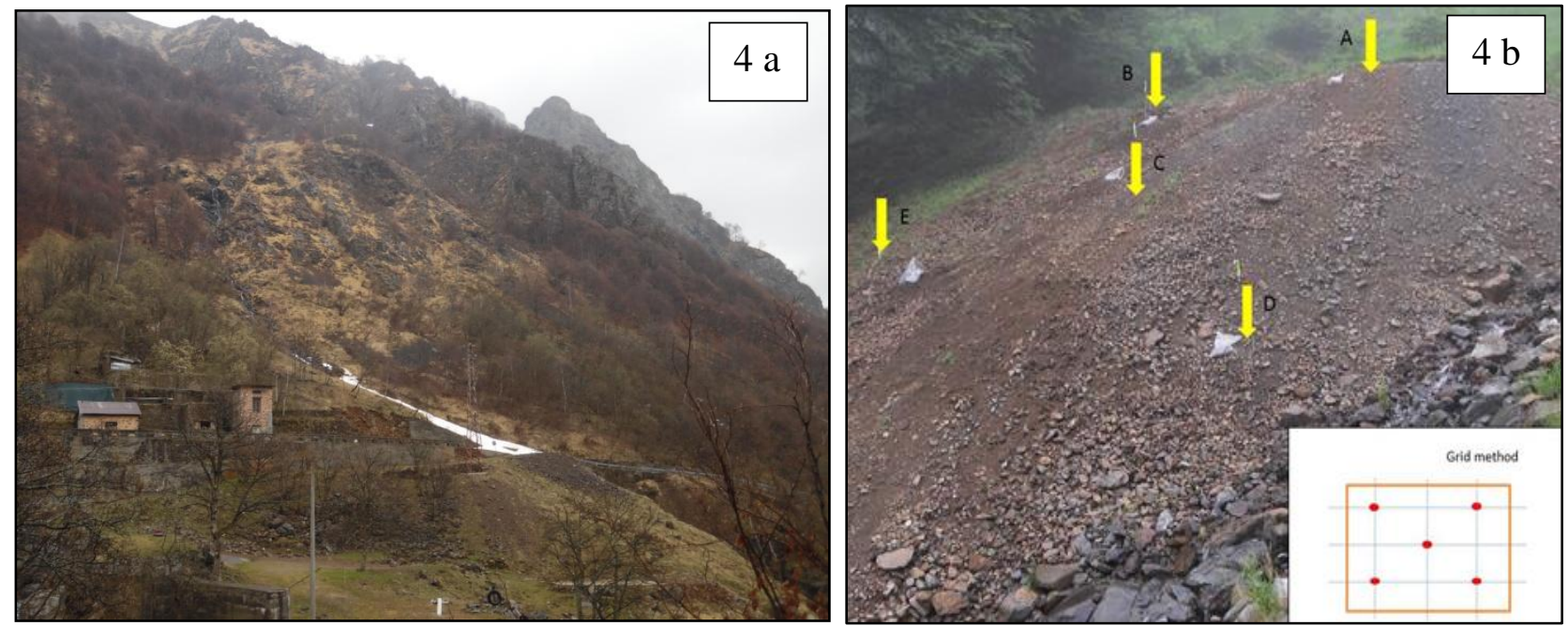

Fig. 4. Waste rock facilities at Campello Monti.

Fig. 4a) General overview of the Campello Monti waste rock facilities.

Fig. 4b) Sampling activity at the Campello Monti waste rock facilities. Net Scheme.

\subsubsection{Water sampling}

In Campello Monti, two water sampling campaigns were conducted in July and October of 2016. Water samples were collected as groundwater $(\mathrm{GW})$ from springs and water flowing from tunnels and surface water (SW) in the Strona stream and minor creeks in the valley. During the two sampling campaigns, a total of 11 groundwater samples and 7 surface water samples were collected. The sample locations are shown in Fig. 4. 


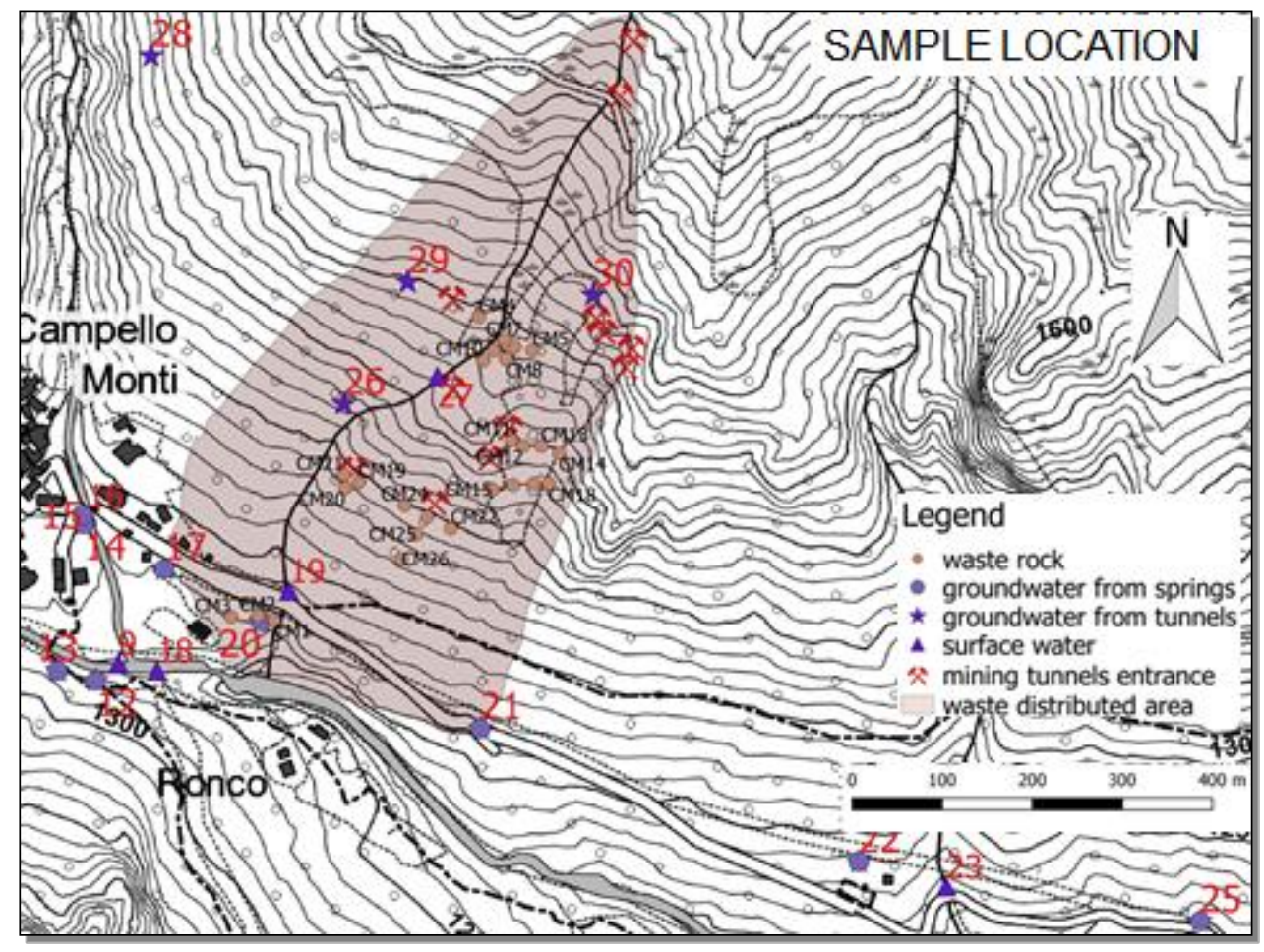

Fig. 5. Waste rock and water sample locations.

\subsection{Analytical Methods}

The extractive waste samples were dried in an oven for a period of 24 hours to remove any moisture. The samples were then sieved through $20-\mathrm{mm}$ and $2-\mathrm{mm}$ sieves to determine the weights of different fractions. $\mathrm{pH}$ was measured in 1:2.5 suspensions of the waste rock samples in water (ISO 10390). The samples were analysed for their concentrations of chemical elements on the fractions of less than $2 \mathrm{~mm}$ using the method described in EPA 3051A, (2007) and EPA 6010 C, (2007). The concentrations for risk analysis were calculated on fractions of less than $20 \mathrm{~mm}$ following risk analysis guidelines (Ministero dell'ambiente e della tutela del territorio, 2006, APAT, 2008). The concentrations of arsenic, antimony, beryllium, cadmium, cobalt, chromium, mercury, nickel, lead, copper, selenium, tin, thallium, vanadium and zinc were measured using an Ametek Spectro Genesis Inductively Coupled Plasma- Optical Emission Spectrometer (ICP-OES). The instrument was provided with an Ametek monochromator, a cyclonic spray chamber and a Teflon Mira Mist nebulizer. The instrumental conditions included a plasma power of $1.3 \mathrm{~kW}$, sample aspiration rate of $30 \mathrm{rpm}$, argon nebulizer flow of $1 \mathrm{~L} / \mathrm{min}$, argon auxiliary flow of $1 \mathrm{~L} / \mathrm{min}$ and argon plasma flow of $12 \mathrm{~L} / \mathrm{min}$. All the reagents used were of analytical grade. All metal solutions were prepared from concentrated stock solutions (Sigma Aldrich). High-purity water (HPW) produced with a Millipore Milli-Q Academic system was used throughout the analytical process.

The water samples were measured for total alkalinity (sum of $\mathrm{CO}_{3}{ }^{2-}+\mathrm{HCO}_{3}{ }^{-}$), bicarbonate and carbonate alkalinity using the potentiometric method. Anions $\left(\mathrm{NO}_{2}^{-}, \mathrm{F}^{-}, \mathrm{SO}_{4}{ }^{2-}, \mathrm{NO}_{3}{ }^{-}, \mathrm{Cl}^{-}\right)$were measured using a 761 Compact IC Metrohm Ion chromatograph with chemical suppression $\left(\mathrm{H}_{2} \mathrm{SO}_{4}\right.$ $50 \mathrm{mM}$ ) and equipped with a monolithic gel column Metrosep a supp $5150 \mathrm{~mm}$. The eluent $\left(\mathrm{Na}_{2} \mathrm{CO}_{3}-3.2 \mathrm{mM}+\mathrm{NaHCO}_{3}-1 \mathrm{mM}\right)$ was provided at a flux of $0.7 \mathrm{ml} / \mathrm{min}$. The instrument was equipped with an 813 Compact autosampler with a sampling time of 25 minutes. Before each analysis, the water was filtered using $0.45-\mathrm{mm}$ cellulose nitrate membrane filters, and afterwards, the network was cleaned for $30 \mathrm{~s}$ using ethyl alcohol diluted by $70 \%$ in high-purity water. 
The contents of major and minor metal cations $\left(\mathrm{Ca}^{2+}, \mathrm{Mg}^{2+}, \mathrm{Na}^{+}, \mathrm{K}^{+}, \mathrm{P}, \mathrm{Al}, \mathrm{Ag}, \mathrm{Fe}, \mathrm{Hg}, \mathrm{Ni}, \mathrm{Mn}, \mathrm{B}\right.$, $\mathrm{Ti}, \mathrm{Mo}, \mathrm{Sb}, \mathrm{As}, \mathrm{Be}, \mathrm{Cd}, \mathrm{Co}, \mathrm{Cr}$ (total), $\mathrm{Cr}(\mathrm{VI}), \mathrm{Pb}, \mathrm{Cu}, \mathrm{Se}, \mathrm{Tl}, \mathrm{Zn}$, and $\mathrm{Sn}$ ) were measured using the ICP-OES. Three water samples were analysed for their concentrations of cyanide ions. Those three water samples were taken from 1) the Strona stream to evaluate the presence of cyanide in the main stream (Sample No. 18), 2) the secondary stream that passes through the waste distribution area and is an influent to the Strona stream (Sample No. 19) and 3) the groundwater spring near the Strona stream, which is below the contaminated waste (Sample No. 17).

\subsection{Risk Analysis}

The human health risks and risks to groundwater due to the presence of contaminants in EW and groundwater were evaluated using Risk-net (Floreani and Zorzet, 2016). Risk-net is a software program that allows users to apply the risk analysis procedure to contaminated sites in accordance with the provisions of Risk Based Corrective Action (RBCA) (ASTM, 1995, ASTM, 2015). This method refers to an approach towards managing contaminated sites that examines the risks posed to human health and the environment due to contaminants. The amount of environmental management required to ensure the protection of human health and the environment is based on a scientific assessment of risks posed by contaminants, both now and in the future. It indicates whether sites should be managed to have low and acceptable risk levels rather than bringing them to pristine levels. The permissible limits for the chemical elements for the risk calculations were taken from the Italian Legislative Decree 152/06 and risk analysis guidelines (Ministero dell'ambiente e della tutela del territorio, 2006, APAT, 2008).

The risk was calculated under following conditions: 1) current site characteristics and exposure parameters and 2) an assumption that the waste is transported to the nearest plain area for use as filling material. The comparative risk analysis aims to provide information on EW management.

\subsubsection{Site-specific Conceptual Model}

After carrying out the site surveys and analysing the collected and treated samples, a site-specific conceptual model was prepared. The boxes highlighted in green in Fig. 6 refer to the source, pathways and receptors for Campello Monti and the nearest plain. The groundwater in Campello Monti is contaminated due to past activities, which is not the case for the plain. Thus, the sources, pathway and receptors remain the same for the plain, apart from the contaminated groundwater source.

Distributed EW and the contaminated groundwater form the source.

Residents living in the study area are the receptors of metals through soil ingestion, dust inhalation and dermal contact from superficial soils, whereas residents living at a distance from the source are only exposed to contaminants through dust inhalation. The exposure times of the residents were adjusted after considering the exposures of children and adults in recreational and residential areas.

$>$ The groundwater is a potential receptor of contaminants through leaching from the superficial soil and deep soil layers due to the presence of extractive waste. The EW layer from $0-1 \mathrm{~m}$ was considered to be the superficial soil layer and that from 1-2 $\mathrm{m}$ was considered to be the deep soil layer. 


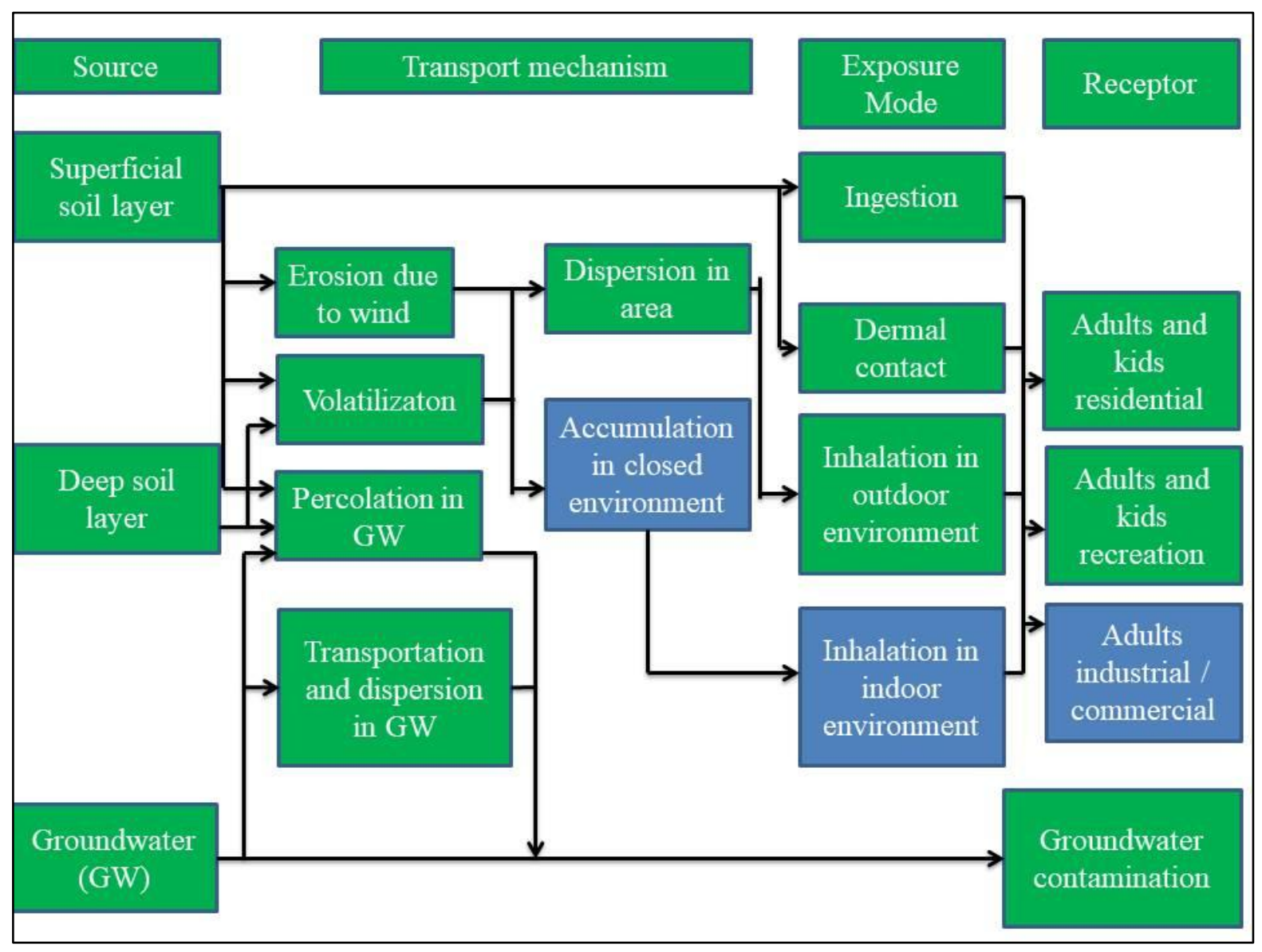

Fig. 6. Site-specific conceptual model developed after site investigations (the active sources, pathways and receptors are highlighted in green, whereas the blue boxes show inactive pathways and receptors for the site).

Because the risk evaluation process considers the most conservative values, the concentrations were considered to be the $95 \%$ upper confidence limits for the concentrations of contaminants at fractions of less than $20 \mathrm{~mm}$ provided by the Pro-UCL software (Daniel, 2015). The present study addresses considering the future use of waste without any treatment or alteration of its chemical or physical properties, and the EW concentrations would remain unchanged in the nearest plain.

\subsubsection{Site characteristics}

Observations collected from the general site setting, field surveys, and previous hydrogeological and climatic studies led to the development of the site characteristics used in the risk analysis (Table 1). Some of the parameters were already fixed in the software, for example, the fractions of organic soil in the unsaturated zone for superficial soil and deep soil ( $f_{\text {oc. }}$ ss and $f_{o c}$ sP), average leaching duration, soil density $\left(\rho_{\mathrm{s}}\right)$, Darcy's velocity $\left(\mathrm{v}_{\mathrm{gw}}\right)$, the average effective rate in the aquifer $\left(\mathrm{v}_{\mathrm{e}}\right)$, the fraction of organic carbon in saturated soil $\left(\mathrm{f}_{\mathrm{oc}}\right)$, dispersivity $\left(\mathrm{a}_{\mathrm{x}}, \mathrm{a}_{\mathrm{y}}\right.$, and $\left.\mathrm{a}_{\mathrm{z}}\right)$, dilution factor in groundwater $(\mathrm{LDF})$, particulate flow rate per unit area in air $\left(\mathrm{P}_{\mathrm{e}}\right)$, average stream flow duration $(\tau$ outdoor $)$, and dispersion coefficients in air $\left(\sigma_{\mathrm{y}}\right.$ and $\left.\sigma_{\mathrm{z}}\right)$.

The study site is almost completely covered by EW; thus, the natural soil has been replaced by a layer of EW in a triangular section with a base of approximately $260 \mathrm{~m}$ and a height of $520 \mathrm{~m}$, as shown in Fig. 4 (waste distribution area). Groundwater flow occurs within the detritic cover and so was assumed to occur at a depth of $2 \mathrm{~m}$. Wind directions in mountainous areas vary greatly at any 
point in time; thus, to arrive at a conservative value, wind flow was assumed to be parallel to the height of the triangle. These characteristics are explained in detail as follows.

$>$ The total thickness of the on-site waste deposits was $2 \mathrm{~m}$, thus leading to superficial soil with a depth of $1 \mathrm{~m}$ and deep soil with a depth of $1 \mathrm{~m}$ in the waste distribution area, as shown in Fig. 4.

> The groundwater flow through the detritic cover and waste dumps was considered to be predominant. The depth to the groundwater level from the top was $2 \mathrm{~m}$, and thus the thickness of the unsaturated zone was $1.9 \mathrm{~m}$, considering that a thickness of $0.1 \mathrm{~m}$ became saturated due to capillary action.

$>$ The hydraulic gradient was approximately equal to the slope of the mountains and was thus 0.3 .

$>$ Out of all the types of soil in the software, the physical properties of the EW within the fractions less than $20 \mathrm{~mm}$ most closely resembled those of sand. Thus, the effective porosity of the source, volumetric air content and volumetric water content of sand were used.

$>$ The infiltration capacity was measured considering an average precipitation of $140 \mathrm{~cm}$ (the average annual precipitation for the period of 1971-2000).

$>$ The wind velocity was taken from a mixing zone height of $2 \mathrm{~m}$, considering a wind velocity measured at a weather station of $3.4 \mathrm{~m} / \mathrm{s}$.

If extractive waste is transported to the nearest plain and used as a by-product for use as filling material for an area of $100 \times 100 \mathrm{~m}^{2}$, the site characteristics will vary from the initial metamorphic rock conditions. For example, the hydraulic gradients in plains are considerably lower, the infiltration capacities vary due to changes in annual precipitation, and groundwater depths also change. As the area to be filled is considered to have a square shape, the final risk to groundwater is independent of wind and groundwater flow directions. The site characteristics are explained below in detail.

$>$ If EW is used as a filling material in an area of $100 \times 100 \mathrm{~m}^{2}$ and a height of $8 \mathrm{~m}$, the top $1 \mathrm{~m}$ can be taken as superficial soil, and the remaining $7 \mathrm{~m}$ can be taken as deep soil.

$>$ The depth to the groundwater level from the top was $10 \mathrm{~m}$, and thus the thickness of the unsaturated zone was $9.9 \mathrm{~m}$.

$>$ The hydraulic gradient was 0.0027 , following a map of the hydraulic gradients in the Piemonte region.

$>$ The properties of the waste remained the same as in the original location.

$>$ The infiltration capacity was measured considering an annual precipitation of $100 \mathrm{~cm}$ (the average annual precipitation for the period of 1971-2000).

Table 1. Unsaturated zone, saturated zone and outside environment properties at Campello Monti and the nearest plain area

\begin{tabular}{|c|c|c|c|c|}
\hline \multicolumn{2}{|c|}{ Parameter } & Units & $\begin{array}{l}\text { Campello } \\
\text { Monti }\end{array}$ & $\begin{array}{l}\text { Nearest } \\
\text { plain }\end{array}$ \\
\hline $\mathbf{L}_{\mathbf{s}(\mathbf{S S})}$ & $\begin{array}{l}\text { Depth of the top of the source in the } \\
\text { surface soil relative to the surface level }\end{array}$ & $\mathrm{m}$ & 0 & 0 \\
\hline $\mathbf{L}_{\mathbf{s}(\mathbf{S P})}$ & $\begin{array}{l}\text { Depth of the top of the source in the } \\
\text { deep soil relative to the surface level }\end{array}$ & $\mathrm{m}$ & 1 & 1 \\
\hline d & $\begin{array}{l}\text { Thickness of the source of } \\
\text { contamination in the surface soil } \\
\text { (unsaturated) }\end{array}$ & $\mathrm{m}$ & 1 & 1 \\
\hline
\end{tabular}




\begin{tabular}{|c|c|c|c|c|}
\hline $\mathbf{d}_{\mathrm{s}}$ & $\begin{array}{l}\text { Thickness of the source of } \\
\text { contamination in the deep soil } \\
\text { (unsaturated) }\end{array}$ & $\mathrm{m}$ & 1 & 7 \\
\hline $\mathbf{L}_{\mathbf{G W}}$ & $\begin{array}{l}\text { Depth of the groundwater level (total } \\
\text { from the top) (phreatic level) }\end{array}$ & $\mathrm{m}$ & 2 & 10 \\
\hline $\mathbf{h}_{\mathbf{v}}$ & Thickness of the unsaturated zone & $\mathrm{m}$ & 1.9 & 9.9 \\
\hline pH & $\mathrm{pH}$ & & 5.8 & 5.8 \\
\hline $\mathbf{I}_{\text {ef }}$ & Effective infiltration & $\mathrm{cm} /$ year & 35.3 & 18 \\
\hline $\mathbf{P}$ & Precipitation & $\mathrm{cm} /$ year & 140 & 100 \\
\hline $\mathbf{W}$ & $\begin{array}{l}\text { Extension of the source in the direction } \\
\text { of groundwater flow }\end{array}$ & $\mathrm{m}$ & 520 & 100 \\
\hline $\mathbf{S}_{\mathbf{w}}$ & $\begin{array}{l}\text { Extension of the source in the direction } \\
\text { perpendicular to the groundwater flow }\end{array}$ & $\mathrm{m}$ & 260 & 100 \\
\hline $\mathbf{d}_{\mathrm{a}}$ & Aquifer thickness & $\mathrm{m}$ & 2 & 20 \\
\hline $\mathbf{K}_{\text {sat }}$ & Hydraulic conductivity of saturated soil & $\mathrm{m} / \mathrm{s}$ & $5 \times 10^{-4}$ & $1 \times 10^{-4}$ \\
\hline i & Hydraulic gradient & & 0.3 & 0.0027 \\
\hline $\mathbf{v}_{\mathbf{g w}}$ & Darcy's velocity & $\mathrm{m} / \mathrm{s}$ & $1.5 \times 10^{-4}$ & $2.7 \times 10^{-7}$ \\
\hline $\mathbf{v}_{\mathbf{e}}$ & Average effective rate in the aquifer & $\mathrm{m} / \mathrm{s}$ & $3.9 \times 10^{-4}$ & $7.65 \times 10^{-7}$ \\
\hline $\boldsymbol{\theta}_{\text {e sat }}$ & $\begin{array}{l}\text { Effective porosity of the ground in the } \\
\text { saturated zone }\end{array}$ & & 0.385 & 0.353 \\
\hline POC & $\begin{array}{l}\text { Distance of the receptor (off-site) } \\
\text { (DAF) }\end{array}$ & $\mathrm{m}$ & 0 & 0 \\
\hline $\boldsymbol{\delta}_{\mathrm{gw}}$ & $\begin{array}{l}\text { Thickness of the mixing zone in the } \\
\text { aquifer }\end{array}$ & $\mathrm{m}$ & 2 & 12.6 \\
\hline LDF & Dilution factor in groundwater & calculated & 52.6 & 6.96 \\
\hline $\mathbf{W}^{\prime}$ & $\begin{array}{l}\text { Extension of the source into the main } \\
\text { wind direction }\end{array}$ & $\mathrm{m}$ & 520 & 100 \\
\hline $\mathbf{S}_{\mathbf{w}}{ }^{\prime}$ & $\begin{array}{l}\text { Spring extension in the direction } \\
\text { orthogonal to that of the wind }\end{array}$ & $\mathrm{m}$ & 260 & 100 \\
\hline $\mathbf{U}_{\text {air }}$ & Wind velocity & $\mathrm{m} / \mathrm{s}$ & 2.97 & 1.24 \\
\hline
\end{tabular}

\subsubsection{Risk calculation and characterization}

The risk calculations and characterizations for different categories were performed using the following procedure:

1) The non-carcinogen health risk to the local habitants through rock waste (that forms the superficial layer) was measured on the basis of the hazard quotient (HQ). HQ is the ratio of the estimated daily exposure of a contaminant through different pathways to the reference dose. It is based on Eqs. (1), (2), (3) and (4) for the inhalation, ingestion and dermal contact of a particular contaminant (U.S.EPA, 2009):

$\mathrm{HQ}=\mathrm{HQ}_{\text {ingestion }}+\mathrm{HQ} \mathrm{inhalation}_{\text {}}+\mathrm{HQ}$ dermal contact, 
$\mathrm{HQ}_{\text {ingestion }}=\mathrm{CRS} . \quad\left(\frac{\mathrm{EM}_{\text {ing. }} \cdot 10^{-6} \mathrm{~kg} / \mathrm{mg}}{\mathrm{RfD}_{\text {ing }}}\right)$,

$\mathrm{HQ}_{\text {inhalation }}=\mathrm{CRS} .\left(\frac{\mathrm{EM}_{\mathrm{inh}} \cdot \mathrm{PEF} \cdot \mathrm{ADF}}{\mathrm{RfD}_{\text {inh }}}\right) \quad$ (unitless), and

$\mathrm{HQ}_{\text {dermal contact }}=\mathrm{CRS} . \quad\left(\frac{\mathrm{EM}_{\mathrm{conD}} \cdot 10^{-6} \mathrm{~kg} / \mathrm{mg}}{\mathrm{RfD}_{\text {ing }}}\right) \quad$ (unitless),

where

$\mathrm{CRS}=$ concentration of the contaminant in the source $(\mathrm{mg} / \mathrm{kg})$,

$\mathrm{EM}_{\text {ing }}=$ factor of ingestion,

$\mathrm{EM}_{\mathrm{inh}}=$ factor of inhalation,

$\mathrm{EM}_{\mathrm{conD}}=$ factor of dermal contact,

$\mathrm{RfD}_{\text {ing }}=$ reference dose for ingestion,

$\mathrm{RfD}_{\text {inh }}=$ reference dose for inhalation

$\mathrm{PEF}=$ outdoor particle concentration, and

$\mathrm{ADF}=$ atmospheric dispersion (for on-site exposure, $\mathrm{ADF}=1$ ).

The Hazard Index (HI) is equal to the sum of the HQs for all the contaminants (Eq. (5)) and is used to assess the overall potential for noncarcinogenic effects posed by more than one contaminant at a site.

$\mathrm{HI}=\sum_{m=1}^{n} H Q_{m}$,

where $\mathrm{n}=$ no. of contaminants.

$\mathrm{HI}<1$ indicates that there is no significant risk of noncarcinogenic effects. Conversely, if the ratio is $>1$, the exposed population is likely to experience obvious non-carcinogenic effects with a probability that tends to increase as the value of $\mathrm{HI}$ increases.

2) Carcinogenic risk (RI) to human beings is calculated by adding the carcinogenic risks due to ingestion, inhalation and dermal contact for a particular contaminant in the source on the basis of slope factors, as shown in Eqs. (6), (7), (8) and (9):

$\mathrm{RI}=\mathrm{RI}_{\text {ingestion }}+\mathrm{RI} \mathrm{I}_{\text {inhalation }}+\mathrm{RI} \mathrm{I}_{\text {dermal contact, }}$

$\mathrm{RI}_{\text {ingestion }}=\mathrm{CRS}$. $\mathrm{SF}_{\text {ing. }} . \mathrm{EM}_{\text {ing. }} \cdot 10^{-6} \mathrm{~kg} / \mathrm{mg}$,

$\mathrm{RI}_{\text {inhalation }}=\mathrm{CRS} . \mathrm{SF}_{\text {ing }} . \mathrm{EM}_{\text {inh. }} . \mathrm{PEF} . \mathrm{ADF}$, and

$\mathrm{RI}_{\text {dermal contact }}=\mathrm{CRS} . \mathrm{SF}_{\text {conD }} \cdot \mathrm{EM}_{\text {conD }} \cdot 10^{-6} \mathrm{~kg} / \mathrm{mg}$,

where

$\mathrm{SF}_{\text {ing }}=$ Slope factor for ingestion,

$\mathrm{SF}_{\mathrm{conD}}=$ Slope factor for dermal contact.

If the RI for a single contaminant exceeds $1 \times 10^{-6}$, that element poses a carcinogenic risk to exposed inhabitants, and the probabilities of the carcinogenic effects increase with increasing RI. Total carcinogenic risk was calculated for all contaminants and was used to assess the carcinogenic risk due to more than one chemical element at a site. It is defined in Eq. (10): 
$\mathrm{RI}_{\text {total }}<1 \times 10^{-5}$ indicates that there is no significant carcinogenic risk. Conversely, if $\mathrm{RI}_{\text {total }}>1 \times 10^{-}$ 5 , the exposed population is likely to experience obvious carcinogenic effects with probabilities that tend to increase with increasing $\mathrm{RI}_{\text {total }}$.

3) The risks to groundwater sources due to elements being leached from the soil are calculated using Eq. (11) and (12):

$\mathrm{R}_{\mathrm{SS} . \mathrm{LF}}=\frac{\mathrm{CRS} \cdot \mathrm{LF}_{\mathrm{SS}}}{\mathrm{DAF} \cdot \mathrm{CSC} \cdot 10^{-3} \mathrm{mg} / \mu \mathrm{g}}$, and

$\mathrm{R}_{\mathrm{DS} . \mathrm{LF}}=\frac{\mathrm{CRS} \cdot \mathrm{LF}_{\mathrm{DS}}}{\mathrm{DAF} \cdot \mathrm{CSC} \cdot 10^{-3} \mathrm{mg} / \mu \mathrm{g}}$,

where

$\mathrm{R}_{\mathrm{SS} \text {. LF }}=$ risk to groundwater due to the contaminant in superficial soil,

$\mathrm{R}_{\mathrm{DS} \text {. LF }}=$ risk to groundwater due to the contaminant in deep soil,

$\mathrm{LF}_{\mathrm{SS}}=$ leaching in groundwater from the contaminant in superficial soil,

$\mathrm{LF}_{\mathrm{DS}}=$ leaching in groundwater from the contaminant in deep soil,

$\mathrm{DAF}=$ Factor of dilution in groundwater (for on-site exposure, $\mathrm{DAF}=1$ ), and

CSC $=$ permissible limit of any element in groundwater (Ministero dell'ambiente e della tutela del territorio, 2006).

\subsection{Sensitivity Analysis}

After performing the deterministic static risk analysis, it was found that the major contribution to risk to human health and / or groundwater was due to the presence of $\mathrm{Ni}, \mathrm{Co}, \mathrm{Sb}, \mathrm{As}, \mathrm{Pb}$, and $\mathrm{Cu}$. Following that conclusion, we performed a Monte Carlo analysis using the human health risk calculations to incorporate the individual input distributions of exposure variables to produce the probability distributions of the health risk estimates and to assess uncertainties in the risk assessment (U.S. EPA, 1997). A similar analysis was undertaken to calculate risk to groundwater after incorporating the distributions of the hydrogeological parameters.

Human health risk and risk to groundwater were calculated over 5000 iterations using randomly selected values derived from the individual probability distributions of the corresponding exposure model parameters. The simulation model was also used for sensitivity analysis, in which the relative importance of each input variable was assessed by calculating its contribution to the total variance.

The soil ingestion rate, body weight and exposure frequency were assumed to be uniformly distributed in the following ranges: $100-200 \mathrm{mg} / \mathrm{d}, 15-70 \mathrm{~kg}$, and 250-350 d/y, respectively (U.S. EPA, 2011). The exposure parameters for inhalation and dermal contact exposure pathways were also assumed to be uniformly distributed for both carcinogenic and non-carcinogenic risks.

The wind velocities were assumed to vary uniformly, following the actual wind velocities (at $2 \mathrm{~m}$ height) $\pm 50 \mathrm{~cm} / \mathrm{s}$ for both sites.

Precipitation was chosen based on the individual site locations. An average value of approximately $140 \mathrm{~cm} / \mathrm{y}$, uniformly distributed within the range of $120 \mathrm{~cm} / \mathrm{y}$ and $160 \mathrm{~cm} / \mathrm{y}$, was considered for Campello Monti. An average value of approximately $100 \mathrm{~cm} / \mathrm{y}$, uniformly distributed within the 
range of $80 \mathrm{~cm} / \mathrm{y}$ and $120 \mathrm{~cm} / \mathrm{y}$, was considered for the nearest plain. The ranges of the values of the other site parameters are shown in Table 2. The value of the parameters that were assigned fixed value on the basis of site characteristics are shown in Table 1.

Table 2. Ranges of the input values of the parameters used for the 5000 simulations of the Monte Carlo analysis.

\begin{tabular}{|c|c|c|c|c|}
\hline \multicolumn{5}{|c|}{$\begin{array}{l}\text { Variable parameters used to assess risk to human health and groundwater for Campello Monti and } \\
\text { the nearest plain }\end{array}$} \\
\hline $\begin{array}{l}\text { Variable parameters used to assess human } \\
\text { health risk at Campello Monti and nearest } \\
\text { plain }\end{array}$ & Symbol & Units & $\begin{array}{l}\text { Input } \\
\text { Values }\end{array}$ & Distribution \\
\hline Body weight & $\mathrm{BW}$ & $\mathrm{kg}$ & $15-70$ & uniform \\
\hline Soil Ingestion & IR & $\mathrm{mg} / \mathrm{d}$ & $100-200$ & uniform \\
\hline Exposure frequency & $\mathrm{EF}$ & $\mathrm{d} / \mathrm{y}$ & $250-350$ & uniform \\
\hline Surface area of exposure & SA & $\mathrm{cm}^{2}$ & $2800-5700$ & uniform \\
\hline $\begin{array}{l}\text { Factor of exposure to contaminant for } \\
\text { dermal contact }\end{array}$ & $\mathrm{AF}$ & $\mathrm{mg} / \mathrm{cm}^{2}-\mathrm{d}$ & $0.07-0.2$ & uniform \\
\hline Inhalation outdoor & $\mathrm{EF}_{\text {inh }}$ & $\mathrm{m}^{3} / \mathrm{h}$ & $0.7-0.9$ & uniform \\
\hline Wind velocity Campello Monti & $\mathrm{U}_{\text {air }}$ & $\mathrm{cm} / \mathrm{s}$ & $247-347$ & uniform \\
\hline Wind velocity nearest plain & $\mathrm{U}_{\text {air }}$ & $\mathrm{cm} / \mathrm{s}$ & $72-172$ & uniform \\
\hline \multicolumn{5}{|l|}{$\begin{array}{l}\text { Variable parameters used to assess risk to } \\
\text { groundwater at Campello Monti }\end{array}$} \\
\hline Precipitation / year & $\mathrm{P}$ & $\mathrm{cm} / \mathrm{y}$ & $120-160$ & uniform \\
\hline Thickness of aquifer & $\mathrm{d}_{\mathrm{a}}$ & $\mathrm{cm}$ & 200 & uniform \\
\hline i (hydraulic gradient) & $\mathrm{i}$ & & $0.25-0.35$ & uniform \\
\hline \multicolumn{5}{|l|}{$\begin{array}{l}\text { Variable parameters used to assess risk to } \\
\text { groundwater at nearest plain }\end{array}$} \\
\hline depth of groundwater table & $\mathrm{L}_{\mathrm{gw}}$ & $\mathrm{cm}$ & $900-1100$ & uniform \\
\hline Precipitation / year & $\mathrm{P}$ & $\mathrm{cm} / \mathrm{y}$ & $80-120$ & uniform \\
\hline Thickness of aquifer & $\mathrm{d}_{\mathrm{a}}$ & $\mathrm{cm}$ & $1000-3000$ & uniform \\
\hline
\end{tabular}

\section{Results and discussion}

\section{1 Analysis of extractive waste}

The concentration of the elements in the rock waste and $\mathrm{pH}$ values are shown in Table 3 . The $\mathrm{pH}$ values of the samples were found to be in the slightly acidic range to near-neutral conditions (ranging from a $\mathrm{pH}$ of 5 to a $\mathrm{pH}$ of 7.1, with an average $\mathrm{pH}$ of 5.9).

The results indicated that $\mathrm{Ni}$ was present at considerable concentrations in the samples, with an average concentration of $277 \mathrm{mg} / \mathrm{kg}$, whereas the concentrations varied from as low as $3.5 \mathrm{mg} / \mathrm{kg}$ to as high as $1377 \mathrm{mg} / \mathrm{kg}$. This shows that the fine fraction of the EW currently contains a large amount of Ni. Copper was found to vary from 4.5 to $484 \mathrm{mg} / \mathrm{kg}$, with an average concentration of $120 \mathrm{mg} / \mathrm{kg}$. The $\mathrm{Cr}$ concentrations varied from 6 to $338 \mathrm{mg} / \mathrm{kg}$, with an average concentration of $119 \mathrm{mg} / \mathrm{kg}$. The presences of $\mathrm{Cr}$ and $\mathrm{Cu}$ were consistent with the geological setting and lithology of the area. The concentrations of As varied from 0.09 to $3.09 \mathrm{mg} / \mathrm{kg}$, with an average concentration of $0.85 \mathrm{mg} / \mathrm{kg}$. 
All other elements were found to have concentrations below the Italian permissible limits for soils in recreational and habitation areas. 
2 Table 3. Heavy metal concentrations $(\mathrm{mg} / \mathrm{kg})$ in rock waste samples with sizes of less than $20 \mathrm{~mm}$ from Campello Monti

\begin{tabular}{|c|c|c|c|c|c|c|c|c|c|c|c|c|c|c|c|c|}
\hline Sample & $\mathrm{pH}$ & $\mathrm{Sb}$ & As & $\mathrm{Be}$ & $\mathrm{Cd}$ & Co & $\mathrm{Cr}$ & $\mathrm{Hg}$ & $\mathrm{Ni}$ & $\mathrm{Pb}$ & $\mathrm{Cu}$ & $\mathrm{Se}$ & $\mathrm{Sn}$ & $\mathrm{Tl}$ & $\mathrm{V}$ & $\mathrm{Zn}$ \\
\hline $\begin{array}{l}\text { Permissible } \\
\text { limit }\end{array}$ & & 10 & 20 & 2 & 2 & 20 & 150 & 1 & 120 & 100 & 120 & 3 & 1 & 1 & 90 & 150 \\
\hline CM1 & 6.6 & 0.5 & 0.4 & 0.1 & $<0.1$ & 6.7 & 57.1 & $<0.1$ & 94 & 3 & 29 & $<0.1$ & 0.4 & $<0.1$ & 9.8 & 10 \\
\hline CM2 & \begin{tabular}{|l}
7.1 \\
\end{tabular} & 0.3 & 0.3 & 0.1 & $<0.1$ & 6.5 & 65.9 & $<0.1$ & 84 & $<1$ & 31 & $<0.1$ & 0.3 & $<0.1$ & 11.2 & 5 \\
\hline CM3 & 7.0 & 16.8 & 3.1 & 0.2 & 0.1 & 19.5 & 135.0 & $<0.1$ & 341 & 12 & 171 & $<0.1$ & 1.0 & $<0.1$ & 19.9 & 26 \\
\hline CM4 & 6.7 & 0.6 & 0.8 & 0.1 & $<0.1$ & 14.0 & 198.0 & $<0.1$ & 108 & 2 & 81 & $<0.1$ & 0.2 & $<0.1$ & 19.4 & 7 \\
\hline CM5 & 6.1 & 0.2 & 0.6 & 0.0 & $<0.1$ & 5.4 & 30.0 & $<0.1$ & 146 & 1 & 79 & $<0.1$ & 0.2 & $<0.1$ & 6.2 & 3 \\
\hline CM6 & 5.9 & 0.0 & 0.1 & 0.0 & $<0.1$ & 0.9 & 6.1 & $<0.1$ & 27 & $<1$ & 12 & $<0.1$ & $<0.1$ & $<0.1$ & 1.1 & 1 \\
\hline CM7 & 5.9 & 0.4 & 0.6 & 0.1 & $<0.1$ & 10.6 & 138.1 & $<0.1$ & 170 & 1 & 102 & $<0.1$ & $<0.1$ & $<0.1$ & 5.2 & 6 \\
\hline CM8 & 5.9 & 0.2 & 0.5 & $<0.1$ & $<0.1$ & 6.1 & 107.9 & $<0.1$ & 103 & 1 & 98 & $<0.1$ & 0.1 & $<0.1$ & 5.6 & 4 \\
\hline CM9 & 5.9 & 0.1 & 0.7 & $<0.1$ & $<0.1$ & 6.2 & 73.8 & $<0.1$ & 62 & $<1$ & 37 & $<0.1$ & $<0.1$ & $<0.1$ & 11.3 & 4 \\
\hline CM10 & 5.7 & 0.4 & 1.2 & $<0.1$ & $<0.1$ & 14.3 & 174.0 & $<0.1$ & 235 & 2 & 145 & $<0.1$ & 0.1 & $<0.1$ & 12.2 & 8 \\
\hline CM11 & 6.1 & 1.4 & 1.8 & 0.1 & 0.1 & 46.7 & 252.8 & $<0.1$ & 1377 & 5 & 484 & $<0.1$ & 0.1 & $<0.1$ & 13.4 & 19 \\
\hline CM12 & 6.0 & 0.3 & 0.3 & $<0.1$ & $<0.1$ & 7.0 & 85.4 & $<0.1$ & 135 & $<1$ & 72 & $<0.1$ & $<0.1$ & $<0.1$ & 4.0 & 3 \\
\hline CM13 & 5.7 & 0.9 & 1.4 & 0.1 & 0.1 & 31.8 & 295.8 & $<0.1$ & 821 & 3 & 330 & $<0.1$ & 0.1 & $<0.1$ & 12.1 & 15 \\
\hline CM14 & 5.6 & 0.2 & 0.3 & $<0.1$ & $<0.1$ & 5.1 & 50.8 & $<0.1$ & 100 & 1 & 56 & $<0.1$ & $<0.1$ & $<0.1$ & 3.2 & 2 \\
\hline CM15 & 5.9 & 1.1 & 1.3 & 0.1 & 0.1 & 34.1 & 168.7 & $<0.1$ & 838 & 3 & 317 & $<0.1$ & $<0.1$ & $<0.1$ & 10.2 & 11 \\
\hline CM16 & 5.8 & 0.5 & 0.7 & $<0.1$ & $<0.1$ & 19.2 & 131.9 & $<0.1$ & 464 & 1 & 176 & $<0.1$ & 0.1 & $<0.1$ & 7.7 & 6 \\
\hline CM17 & 5.9 & 0.9 & 1.3 & 0.1 & 0.1 & 39.3 & 336.7 & $<0.1$ & 866 & 2 & 340 & $<0.1$ & 0.1 & $<0.1$ & 11.8 & 14 \\
\hline CM18 & 5.8 & 0.5 & 0.8 & $<0.1$ & $<0.1$ & 9.3 & 123.0 & $<0.1$ & 151 & 1 & 135 & $<0.1$ & 0.1 & $<0.1$ & 7.6 & 5 \\
\hline CM19 & 5.4 & 0.1 & 0.1 & $<0.1$ & $<0.1$ & 1.8 & 21.6 & $<0.1$ & 13 & 1 & 13 & $<0.1$ & $<0.1$ & $<0.1$ & 6.3 & 2 \\
\hline CM20 & 5.6 & 0.1 & 0.1 & $<0.1$ & $<0.1$ & 0.6 & 9.0 & $<0.1$ & 4 & 1 & 4.5 & $<0.1$ & $<0.1$ & $<0.1$ & 3.3 & 1 \\
\hline CM21 & 5.5 & 0.2 & 0.6 & $<0.1$ & $<0.1$ & 3.2 & 61.2 & $<0.1$ & 19 & 3 & 28 & $<0.1$ & 0.2 & $<0.1$ & 23.8 & 5 \\
\hline CM22 & 5.1 & 0.2 & 0.9 & $<0.1$ & $<0.1$ & 9.0 & 87.0 & $<0.1$ & 127 & 1 & 48 & $<0.1$ & $<0.1$ & $<0.1$ & 12.5 & 6 \\
\hline CM23 & 5.0 & 0.3 & 1.0 & $<0.1$ & $<0.1$ & 12.4 & 116.6 & $<0.1$ & 296 & 1 & 75 & $<0.1$ & $<0.1$ & $<0.1$ & 12.2 & 7 \\
\hline CM24 & 5.4 & 0.3 & 1.1 & $<0.1$ & $<0.1$ & 13.6 & 125.6 & $<0.1$ & 214 & 1 & 82 & $<0.1$ & 0.1 & $<0.1$ & 16.1 & 8 \\
\hline CM25 & 5.5 & 0.3 & 0.8 & $<0.1$ & $<0.1$ & 10.3 & 114.8 & $<0.1$ & 177 & $<1$ & 69 & $<0.1$ & 0.1 & $<0.1$ & 14.6 & 7 \\
\hline CM26 & 5.5 & 0.4 & 1.1 & $<0.1$ & $<0.1$ & 15.0 & 124.4 & $<0.1$ & 232 & 1 & 89 & $<0.1$ & $<0.1$ & $<0.1$ & 16.4 & 9 \\
\hline
\end{tabular}


4 Footnotes - The samples were analysed for their concentrations of chemical elements in size fractions of less than 2 mm. The concentrations used in risk analysis were calculated from fractions of less than $20 \mathrm{~mm}$ following risk analysis guidelines (Ministero dell'ambiente e della tutela del territorio, 2006, APAT, 2008). 


\subsection{Water sample analysis}

The results of the analyses performed on water samples are shown in Table 4. It was observed that the temperatures of the water samples varied from $7.0^{\circ} \mathrm{C}$ to $15.6^{\circ} \mathrm{C}$, which can be attributed to the different locations of the water samples and the variations in ambient temperature, as the sampling was conducted in two different months. The water samples were found to have $\mathrm{pH}$ values in the alkaline range, possibly due to the presence of mafic silicate mineral phases such as olivine, pyroxene and anorthitic plagioclase, which would cause the mine waters to be neutralized. A similar phenomenon was observed at a nickel sulphide mine hosted in mafic intrusions in Ballangen, Nordland, Norway (Banks et al. 1997). The water samples had total alkalinities from 10 to $40 \mathrm{mg} / \mathrm{l}$ of $\mathrm{CaCO}_{3}$ equivalent, whereas carbonate alkalinity was almost absent.

In terms of the presence of metals, contamination was present only due to the presence of Ni. Some water samples also showed concentrations greater than the detection limits but less than the maximum allowable concentrations of $\mathrm{Al}, \mathrm{Cu}, \mathrm{Zn}, \mathrm{Co}$, and total $\mathrm{Cr}$, both in groundwater and in surface water. Free cyanides were never detected. The absence of significant contamination might be due to $\mathrm{pH}$ values in the alkaline range that prevented the dissolution of metals.

The nickel concentration was the only parameter that exceeded the permissible limit of $20 \mu \mathrm{g} / \mathrm{l}$ (Ministero dell'ambiente e della tutela del territorio, 2006). The concentrations ranged between values less than the detection limits $(1.0 \mu \mathrm{g} / \mathrm{l})$ and $512 \mu \mathrm{g} / \mathrm{l} ; 9$ samples (5 in $\mathrm{GW}$ and 4 in $\mathrm{SW}$ ) showed concentrations of $<20 \mu \mathrm{g} / \mathrm{l}$, and 8 samples (6 in GW and 2 in SW) showed levels of $>20$ $\mu \mathrm{g} / \mathrm{l}$.

More specifically, the springs on the south of the Strona River have Ni concentrations that are lower than the detection limit. In the north of the valley, the mine tunnels show concentrations that generally exceed $20 \mu \mathrm{g} / \mathrm{l}$ and are as high as $304 \mu \mathrm{g} / \mathrm{l}$. High Ni concentrations are also present downstream of the waste distribution area. In SW, Ni concentrations of much less than $20 \mu \mathrm{g} / \mathrm{l}$ were detected in the stream that crosses Campello Monti and in the Strona River. However, one of the streams that crosses the mine area was found to have Ni levels as high as $512 \mu \mathrm{g} / \mathrm{l}$ at the bottom of the mountainside, after having crossed the entire mine area.

Nickel is present in considerable concentrations because the mines were used for Ni exploitation, and the rock waste dumps were found to have very high concentrations of $\mathrm{Ni}$ in the fine fraction. Moreover, the walls of tunnels might still have Ni in exposed surfaces, which can then be dissolved in groundwater. 
44 Table 4. Physical-chemical properties of the water samples.

\begin{tabular}{|c|c|c|c|c|c|c|c|c|c|c|c|c|c|c|c|c|}
\hline Sample & Date $^{*}$ & type & $\mathrm{pH}$ & temp & $\mathrm{EC}$ & $\begin{array}{l}\text { Total } \\
\text { alkalinity } \\
\mathrm{mg} / \mathrm{l}\end{array}$ & $\mathrm{Ca}^{2+}$ & $\mathrm{Mg}^{2+}$ & $\mathrm{Na}^{+}$ & $\mathrm{K}^{+}$ & $\mathrm{Cl}^{-}$ & $\mathrm{F}^{-}$ & $\mathrm{NO}_{2}^{-}$ & $\mathrm{SO}_{4}{ }^{2-}$ & $\mathrm{NO}_{3}{ }^{-}$ & $\mathrm{Ni}$ \\
\hline & & & & ${ }^{\circ} \mathrm{C}$ & $\mu \mathrm{S} / \mathrm{cm}$ & $\mathrm{CaCO} 3$ & $\mathrm{mg} / \mathrm{l}$ & $\mathrm{mg} / \mathrm{l}$ & $\mathrm{mg} / \mathrm{l}$ & $\mathrm{mg} / \mathrm{l}$ & $\mathrm{mg} / \mathrm{l}$ & $\mathrm{mg} / \mathrm{l}$ & $\mathrm{mg} / \mathrm{l}$ & $\mathrm{mg} / \mathrm{l}$ & $\mathrm{mg} / \mathrm{l}$ & $\mu \mathrm{g} / \mathrm{l}$ \\
\hline 9 & $13 / 07$ & SW & 7.50 & 14.9 & 34.0 & 20 & 7.6 & 0.6 & 0.6 & $<0.5$ & 0.4 & $<0.1$ & $<0.05$ & 3.1 & 0.9 & $<1.0$ \\
\hline 12 & $13 / 07$ & GW & 7.20 & 11.1 & 35.8 & 10 & 4.9 & 1.1 & $<0.5$ & $<0.5$ & 0.2 & $<0.1$ & $<0.05$ & 3.5 & 5.4 & $<1.0$ \\
\hline 13 & $13 / 07$ & GW & 7.09 & 13.3 & 37.4 & 10 & 5.3 & 1.1 & 0.5 & $<0.5$ & 0.2 & $<0.1$ & $<0.05$ & 4.1 & 3.4 & $<1.0$ \\
\hline 14 & $13 / 07$ & GW & 7.50 & 9.6 & 16.7 & 10 & 4.8 & 0.3 & 0.7 & $<0.5$ & 0.2 & $<0.1$ & $<0.05$ & 2.9 & 1.1 & $<1.0$ \\
\hline 16 & $13 / 07$ & SW & 7.38 & 14.5 & 40.7 & 17 & 5.8 & 0.7 & 0.5 & $<0.5$ & 0.2 & $<0.1$ & $<0.05$ & 2.5 & 0.8 & 4.1 \\
\hline 17 & $13 / 07$ & GW & 8.14 & 10.8 & 50.8 & 20 & 5.0 & 3.7 & $<0.5$ & $<0.5$ & 0.5 & $<0.1$ & $<0.05$ & 7.1 & 4.2 & 77.4 \\
\hline 18 & $13 / 07$ & SW & 7.60 & 11.0 & 35.3 & 20 & 7.0 & 0.7 & 0.5 & $<0.5$ & 0.2 & $<0.1$ & $<0.05$ & 2.8 & 1.0 & 1.0 \\
\hline 19 & $13 / 07$ & SW & 7.39 & 11.2 & 75.8 & 30 & 10.2 & 3.8 & 0.6 & $<0.5$ & 0.3 & $<0.1$ & $<0.05$ & 13.5 & 3.1 & 512.0 \\
\hline 20 & $13 / 07$ & GW & 7.38 & 15.6 & 56.7 & 17 & 4.8 & 4.4 & $<0.5$ & $<0.5$ & 0.2 & $<0.1$ & $<0.05$ & 9.7 & 1.0 & 57.8 \\
\hline 21 & $13 / 07$ & GW & 7.46 & 11.0 & 68.5 & 20 & 6.3 & 5.0 & $<0.5$ & $<0.5$ & 0.2 & $<0.1$ & $<0.05$ & 17.9 & 2.1 & 266.0 \\
\hline 23 & $13 / 07$ & SW & 7.35 & 12.3 & 37.0 & 18 & 6.3 & 1.4 & $<0.5$ & $<0.5$ & 0.1 & $<0.1$ & $<0.05$ & 3.8 & 1.5 & 3.2 \\
\hline 25 & $13 / 07$ & GW & 7.63 & 13.5 & 14.3 & 10 & 4.2 & 0.5 & $<0.5$ & $<0.5$ & 0.2 & $<0.1$ & $<0.05$ & 2.2 & 0.2 & $<1.0$ \\
\hline 26 & $19 / 10$ & GW & 7.93 & 8.0 & 127.4 & 40 & 10.0 & 12.2 & $<0.5$ & $<0.5$ & 0.4 & $<0.1$ & $<0.05$ & 27.8 & 0.6 & 12.7 \\
\hline 27 & $19 / 10$ & SW & 7.80 & 8.5 & 54.7 & 20 & 5.1 & 4.8 & $<0.5$ & $<0.5$ & 0.3 & $<0.1$ & $<0.05$ & 13.2 & 0.9 & 97.3 \\
\hline 28 & $19 / 10$ & GW & 7.69 & 7.0 & 121.7 & 50 & 14.2 & 12.1 & 0.7 & 0.6 & 0.6 & $<0.1$ & $<0.05$ & 26.4 & 1.4 & 304.0 \\
\hline 29 & $19 / 10$ & GW & 8.10 & 7.4 & 77.9 & 40 & 6.1 & 9.8 & $<0.5$ & $<0.5$ & 0.3 & $<0.1$ & $<0.05$ & 14.1 & 1.0 & 47.6 \\
\hline 30 & $19 / 10$ & GW & 8.10 & 7.8 & 68.7 & 40 & 11.0 & 4.6 & 0.8 & $<0.5$ & 0.5 & $<0.1$ & $<0.05$ & 7.8 & 0.9 & 31.9 \\
\hline
\end{tabular}

46 Footnotes- (The * sign in the table indicates that the sample was collected in 2016). 


\subsection{Risk Analysis}

The risk analysis results are shown in Table 5 for the current situation at Campello Monti and the nearest plain. The following results were obtained.

Carcinogenic risk was defined as the incremental probability of getting cancer over a lifetime and calculated as the lifetime intake multiplied by a slope factor for individual chemical carcinogens. The potential risks for human receptors were calculated in terms of the Risk Index (RI) for cancercausing elements due to exposure to extractive waste using the procedure described in 2.4.3. There was a presence of carcinogenic risk due to arsenic in Campello Monti, which had an RI equal to $2.73 \times 10^{-6}$. In the nearest plain to Campello Monti, there was no change in carcinogenic risk due to arsenic. This can be attributed to the fact that there were no major changes in the exposure parameters for the two sites. Risk due to ingestion and dermal contact was found to be an important contributor to overall carcinogenic risk.

The potential risks for human receptors were calculated in terms of Hazard Quotient (HQ) for noncarcinogenic elements. The total organ HI was calculated by summing over all contaminants, assuming the additive effects of multiple chemicals (U.S. EPA, 1989). The Hazard Index was found to be greater than 1 for both Campello Monti and the nearest plain. The major risk contributors were $\mathrm{Ni}$ and Co. This shows that the area is not free from risk to human beings due to the presence of EW. This can be considered as an input should future activity for reuse or to recover the extractive waste to be undertaken at this site.

The groundwater was at risk due to the presence of $\mathrm{Ni}$ in Campello Monti, which was also observed from the water analyses. For the second case, the risk to groundwater due to the presence of $\mathrm{Ni}$ increased, and the groundwater was also observed to be at risk due to the leaching of Co. This is because, 1) for the case of filling activities in the plain, the depth of the deep soil layer in the plain exceeded that in the Campello Monti and the 2) geological conditions and climate of the Campello Monti and plain area differ, which were considered when entering site characteristics into risk equations. It should be noted that these results refer to the worst condition, i.e., to a Point of Compliance (POC) positioned directly in the groundwater under the contamination source (i.e., POC = 0). A displacement in the POC position may lead to further attenuations in the concentrations of groundwater contaminants as a consequence of transport and dispersion phenomena.

The results obtained for both cases show that before pursuing any reuse method that includes transporting rock waste, it can be a good practice to perform a preliminary risk assessment, assuming the same properties as the original waste but with changes in the geology, hydrogeology, hydrography and climate of the area. This might prevent any public unrest over the transportation of extractive waste and additional costs to preserve the environment in the new location. Consideration of these factors may lead to more viable and sustainable solutions for EW management. 
88 Table 5. Human health risks and risks to groundwater in Campello Monti and the nearest plain.

\begin{tabular}{|c|c|c|c|c|c|c|c|c|c|}
\hline \multirow[b]{3}{*}{ Contaminant } & \multirow[b]{3}{*}{$\begin{array}{l}\text { CRS } \\
\text { [mg/kg. d.m.] }\end{array}$} & \multirow{2}{*}{\multicolumn{2}{|c|}{\begin{tabular}{|c|}
$\begin{array}{c}\text { Superficial layer Campello } \\
\text { Monti }\end{array}$ \\
Human health risk
\end{tabular}}} & \multirow{2}{*}{\multicolumn{2}{|c|}{\begin{tabular}{|l|}
$\begin{array}{l}\text { Superficial layer in the nearest } \\
\text { plain }\end{array}$ \\
Human health risk \\
\end{tabular}}} & \multicolumn{2}{|c|}{ Campello Monti } & \multicolumn{2}{|l|}{ Nearest plain } \\
\hline & & & & & & \multirow{2}{*}{\begin{tabular}{|l|} 
Superficial \\
layer \\
Risk to \\
groundwater \\
(RGW)
\end{tabular}} & \multirow{2}{*}{\begin{tabular}{|l|} 
Deep layer \\
Risk to \\
groundwater \\
(RGW)
\end{tabular}} & \multirow{2}{*}{$\begin{array}{l}\text { Superficial } \\
\text { layer } \\
\text { Risk to } \\
\text { groundwater } \\
(\mathrm{RGW})\end{array}$} & \multirow{2}{*}{\begin{tabular}{|l|} 
Deep layer \\
$\begin{array}{l}\text { Risk to } \\
\text { groundwater } \\
(\mathrm{RGW})\end{array}$ \\
\end{tabular}} \\
\hline & & $\begin{array}{l}\text { Carcinogenic } \\
\text { Risk } \\
(\mathrm{RI})\end{array}$ & $\begin{array}{l}\text { Hazard } \\
\text { Quotient } \\
\text { (HQ) }\end{array}$ & $\begin{array}{l}\text { Carcinogenic } \\
\text { Risk (RI) }\end{array}$ & $\begin{array}{l}\text { Hazard Quotient } \\
\text { (HQ) }\end{array}$ & & & & \\
\hline Antimony & 1.26 & --- & 0.04 & --- & 0.04 & 0.05 & 0.10 & 0.08 & 0.62 \\
\hline Arsenic & 1.06 & $2.73 \times 10^{-6}$ & 0.05 & $2.73 \times 10^{-6}$ & 0.05 & 0.03 & 0.07 & 0.05 & 0.41 \\
\hline Cadmium & 0.03 & $1.74 \times 10^{-11}$ & $9.62 \times 10^{-4}$ & $1.28 \times 10^{-12}$ & $9.57 \times 10^{-4}$ & $9.46 \times 10^{-4}$ & $1.90 \times 10^{-3}$ & $1.43 \times 10^{-3}$ & 0.01 \\
\hline Cobalt & 18.90 & --- & & --- & & & & & 0.9 \\
\hline $\begin{array}{l}\text { Chromium } \\
\text { (total) }\end{array}$ & 160.00 & --- & $3.05 \times 10^{-3}$ & --- & $1.53 \times 10^{-3}$ & $1.7 \times 10^{-5}$ & $3.4 \times 10^{-5}$ & $2.56 \times 10^{-5}$ & $1.99 \times 10^{-4}$ \\
\hline Nickel & 427.00 & $2.87 \times 10^{-8}$ & 0.3 & $2.12 \times 10^{-9}$ & 0.3 & 3.12 & 6.24 & 4.72 & 36.71 \\
\hline Lead & 2.60 & --- & $9.73 \times 10^{-3}$ & --- & $9.73 \times 10^{-3}$ & 0.003 & 0.005 & 0.004 & 0.032 \\
\hline Copper & 173.00 & --- & 0.06 & --- & 0.06 & 0.05 & 0.09 & 0.07 & 0.55 \\
\hline Selenium & 0.02 & --- & $5.26 \times 10^{-5}$ & -- & $5.26 \times 10^{-5}$ & 0.004 & 0.006 & 0.006 & 0.044 \\
\hline Vanadium & 1.25 & --- & 0.04 & --- & 0.04 & & NA & NA & NA \\
\hline Zinc & 9.98 & --- & $4.37 \times 10^{-4}$ & --- & $4.37 \times 10^{-4}$ & $5.1 \times 10^{-4}$ & 0.001 & $7.71 \times 10^{-4}$ & 0.006 \\
\hline
\end{tabular}




\subsection{Sensitivity analysis}

To evaluate the potential impacts resulting from a wide range of site conditions, a Monte Carlo analysis was performed with 5000 simulations and randomly varying the input parameters within the ranges reported in Table 2. The source concentration values were used for the concentrations of $\mathrm{Sb}, \mathrm{As}, \mathrm{Ni}, \mathrm{Co}, \mathrm{Cu}$, and $\mathrm{Pb}$. Fig. 7. displays the cumulative probability distributions of the simulated results and their associated sensitivity analyses for cancer risk, human health risk due to chronic exposure, and risk to groundwater, for both Campello Monti and the nearest plain.

For the cancer risk at Campello Monti, the $95 \%$ upper-bound estimate was $19.4 \times 10^{-6}$. The sensitivity analysis showed that body weight (BW) and the factor of exposure to the contaminant for dermal contact (AF) made the greatest contributions to the variance of the cancer risk estimates, whereas surface area (SA) and exposure frequency (EF) accounted for another $7.8 \%$ and $2.7 \%$, respectively. For the cancer risk at the nearest plain, the $95 \%$ upper-bound estimate was $19.8 \times 10^{-}$ 6 . The sensitivity analysis showed that the parameters contributing to the variance in cancer remained the same but with small percent differences when compared to those of Campello Monti.

The $95 \%$ upper bound estimate for the total organ HI value at Campello Monti was found to be 0.72 . The results showed that for $99 \%$ of the cases, the HI value was less than 1 . The sensitivity analysis showed that body weight (BW) and ingestion rate (IR) made the greatest contributions to the variances in the HI values, and exposure frequency (EF) accounted for another $3.2 \%$. The $95 \%$ upper bound estimate for the total organ $\mathrm{HI}$ value at the nearest plain was found to be 0.72 .

The $95 \%$ upper bound estimate for total risk to groundwater at Campello Monti was found to be 13.54. The $95 \%$ upper bound estimate for total risk to groundwater at the nearest plain to Campello Monti was found to be 59.6. The sensitivity analysis showed that precipitation (P) contributed most to the variance of risk to groundwater due to the presence of contaminants in the superficial and deep soil layers.

The presence of risk to human health and groundwater in the plain nearest Campello Monti shows that efforts should be made to reduce them during application of reuse methods. To reduce the probability of groundwater contamination due to the presence of chemical elements in extractive waste, a low- to no-permeability layer can be placed between the ground surface and the EW. This can lead to reductions in EW contaminants leaching into groundwater.

It should be noted that ingestion was found to be the pathway that contributed most to carcinogenic and non-carcinogenic risks. Therefore, during application of reuse methods, efforts should be made to reduce residents' exposure through ingestion pathways. This can be undertaken by installing covers and/or raising awareness among the general public. 


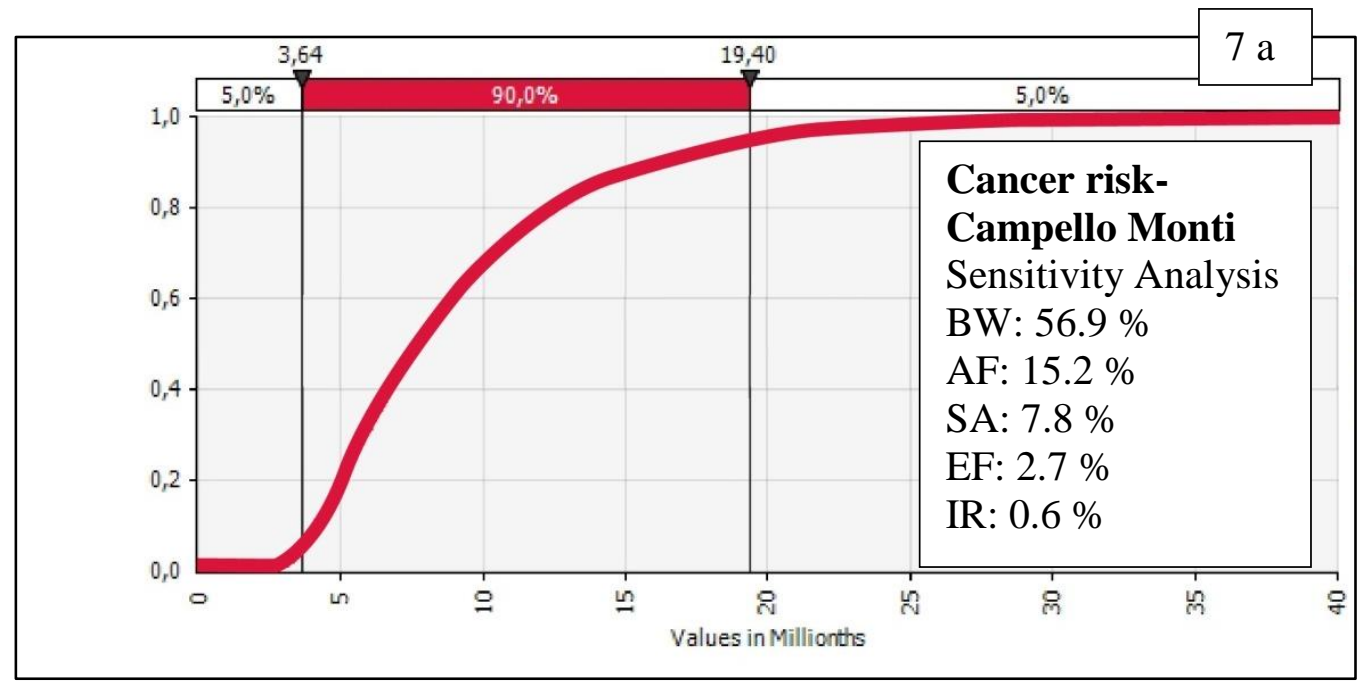

130

131

132

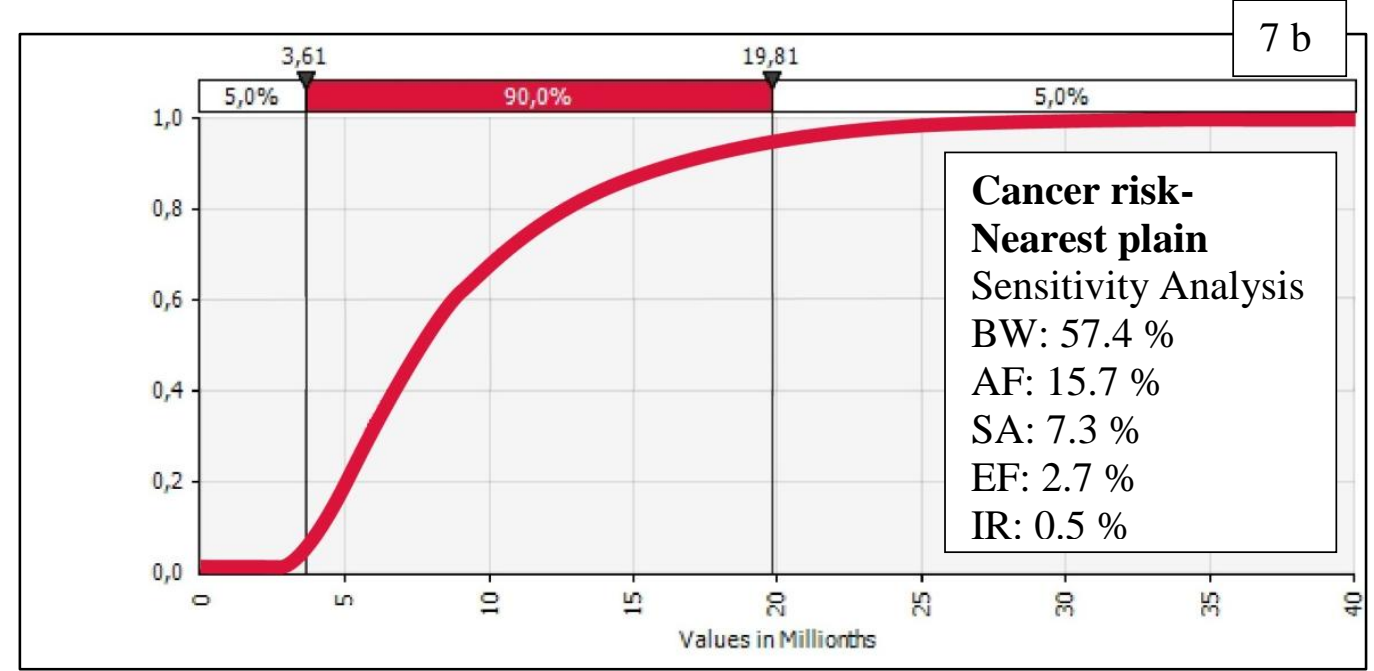

Cancer risk-

Sensitivity Analysis

BW: $57.4 \%$

AF: $15.7 \%$

SA: $7.3 \%$

EF: $2.7 \%$

IR: $0.5 \%$

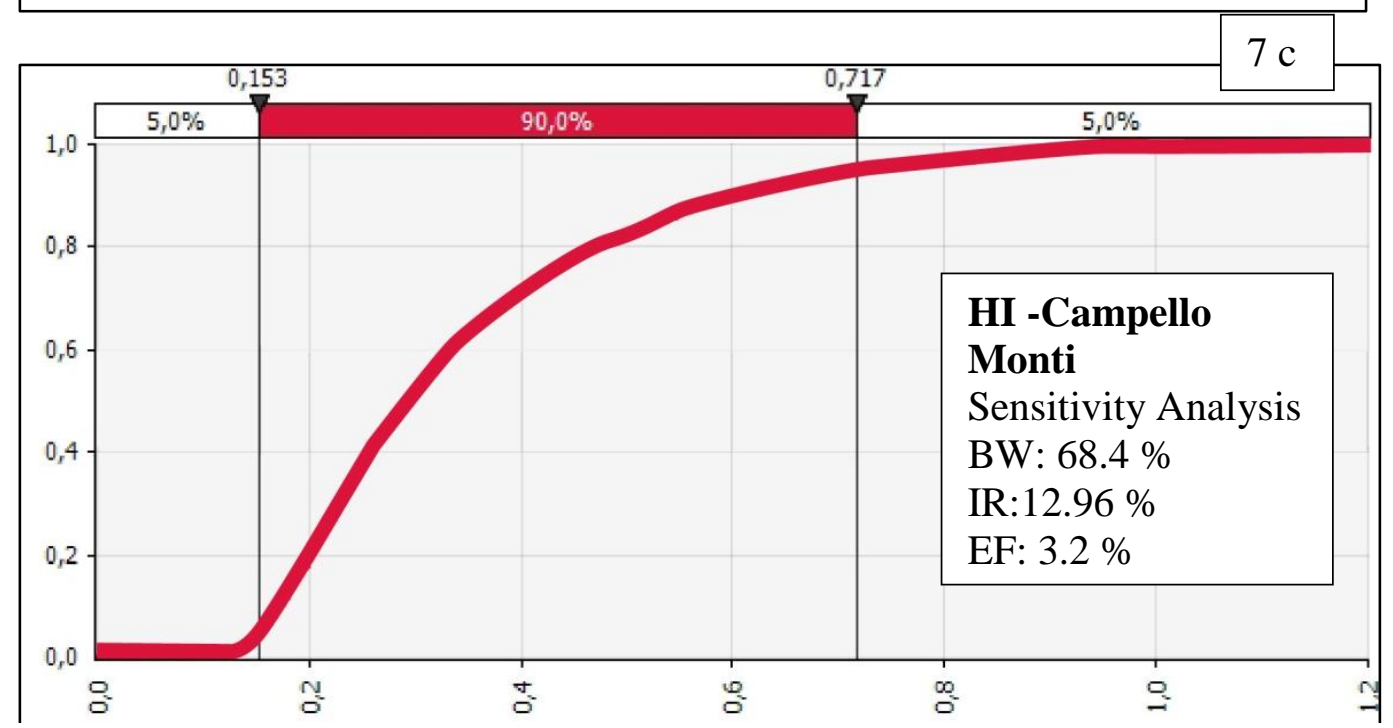




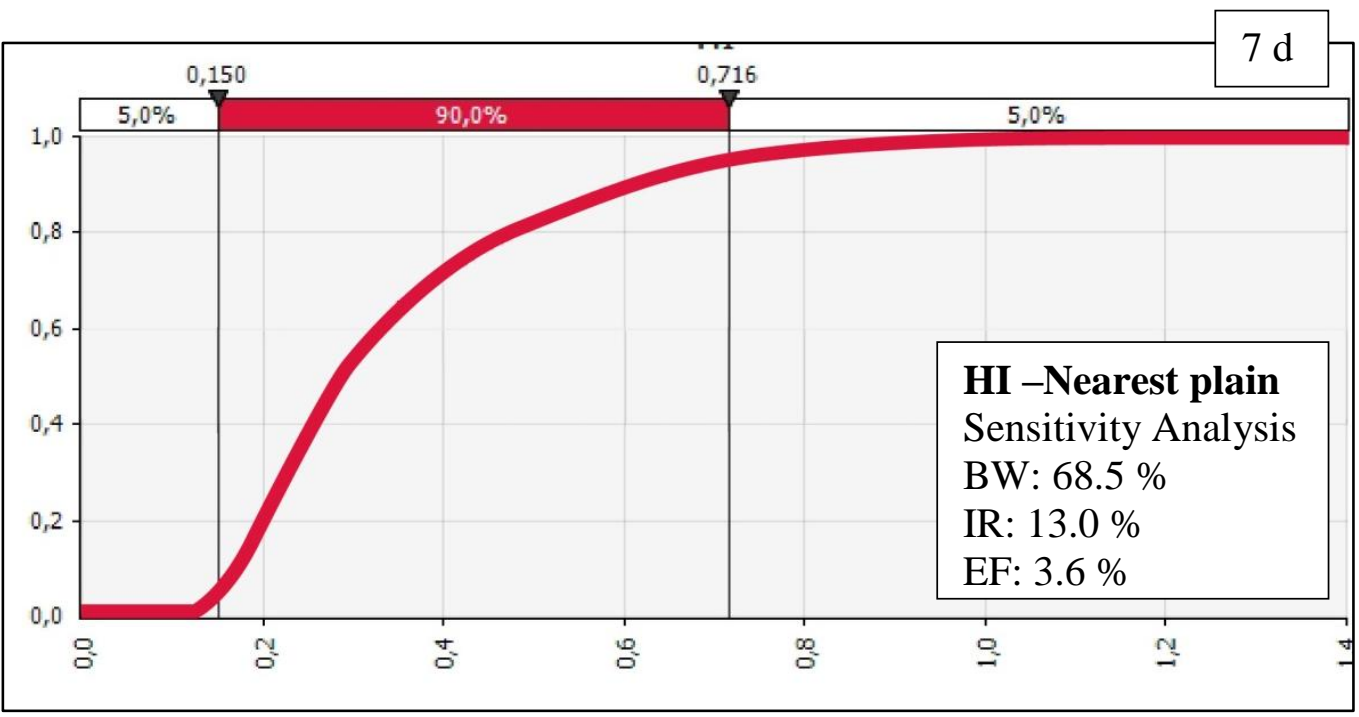

135
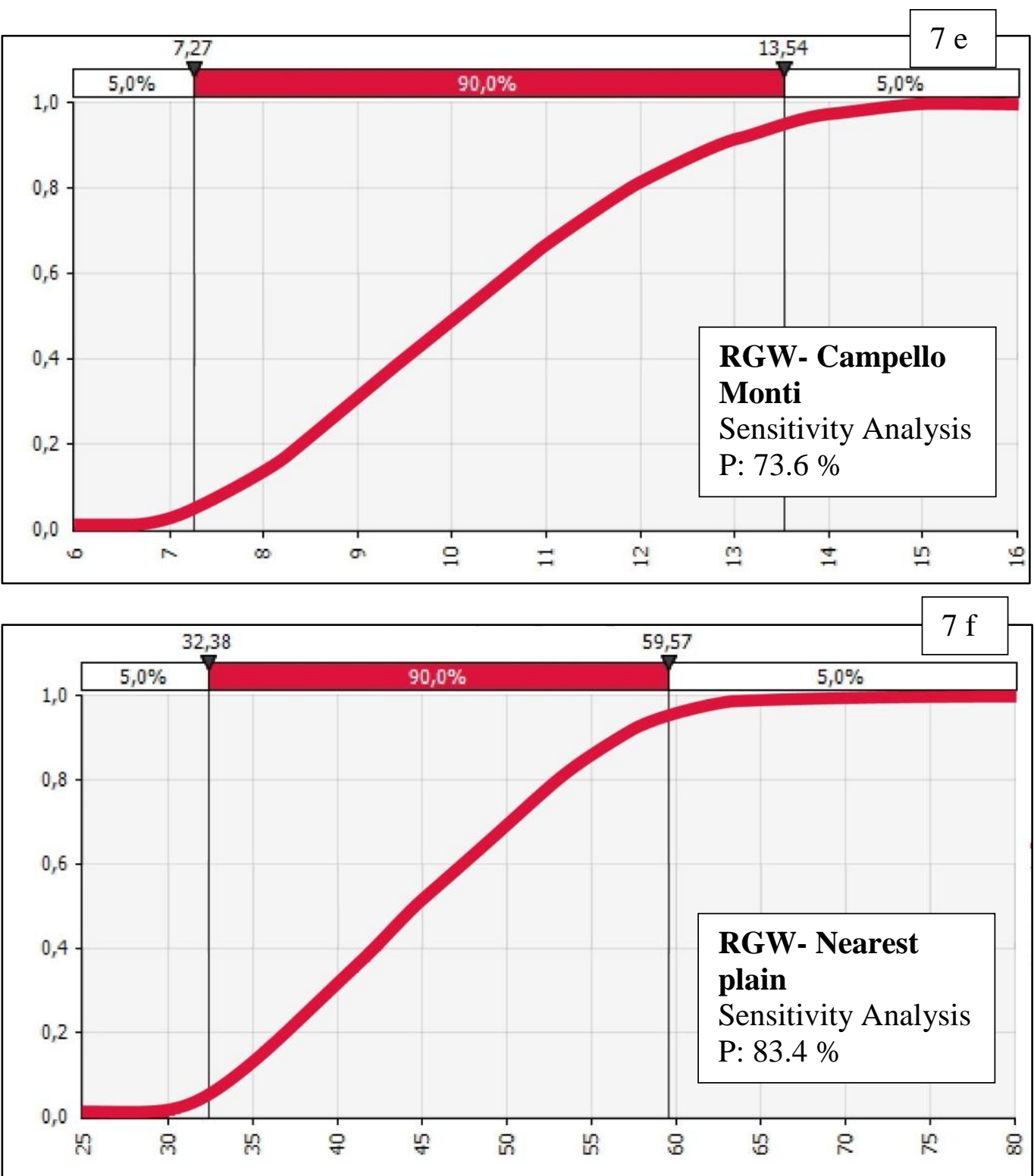

Fig. 7. Potential risks to human health and groundwater expressed in terms of cumulative frequency calculated through a Monte Carlo analysis.

1427 a) Carcinogenic risk at Campello Monti expressed as cumulative frequency of RI. 
7 b) Carcinogenic risk at the nearest plain to Campello Monti expressed as cumulative frequency of RI.

7 c) Human health risk at Campello Monti expressed as cumulative frequency of HI.

$7 \mathrm{~d}$ ) Human health risk at the nearest plain to Campello Monti expressed as cumulative frequency of HI.

7 e) Risk to groundwater at Campello Monti expressed as cumulative frequency of RGW.

$7 \mathrm{f}$ ) Risk to groundwater at the nearest plain to Campello Monti expressed as cumulative frequency of RGW.

\section{Conclusions}

Risk analysis studies can be used to determine risks in existing situations and future reuse scenarios and thus can aid in determining the usability of extractive waste. To address the human health risk to inhabitants via soil ingestion, dust inhalation and dermal contact, elemental analyses of waste samples were performed.

This study has provided new data on the heavy metal concentrations of EW in the area. The EW samples were found to be rich in $\mathrm{Ni}$, with average concentrations of up to $277 \mathrm{mg} / \mathrm{kg}$. As, $\mathrm{Cr}$ and $\mathrm{Cu}$ were also significantly present, with average concentrations of $0.8,119$ and $120 \mathrm{mg} / \mathrm{kg}$, respectively. The water sample analysis aided in determining the hydrogeochemical characteristics of the area. The water samples were found to be contaminated by Ni.

The study focused on comparisons of human health risk and risk to groundwater due to extractive waste at Campello Monti, hypothesizing the transportation of EW to the nearest plain for land rehabilitation. The risk analysis for the current situation at Campello Monti showed a carcinogenic risk of $2.73 \times 10^{-6}$ due to the presence of As. The same waste poses risks to groundwater due to Ni, $\mathrm{As}, \mathrm{Sb}$, and $\mathrm{Pb}$. The risk analysis for the nearest plain pointed towards human health risks. Risks to groundwater were due to the presence of only $\mathrm{Co}$ and $\mathrm{Ni}$, given the changes in the geological features of the site.

The sensitivity and uncertainty analyses for the elements of major concern were performed using Monte Carlo analysis. The analysis used the concentrations of $\mathrm{Ni}, \mathrm{Co}, \mathrm{As}, \mathrm{Sb}, \mathrm{Pb}, \mathrm{Cu}$ as the source concentrations. The sensitivity analysis showed that body weight was a major contributor to the variance in human health risk. Moreover, precipitation made the greatest contribution to the variance in risk to groundwater due to the presence of contaminants in the superficial and deep soil layers.

The risk analysis procedure pointed towards unacceptable risks due to extractive waste both in the current situation and after transporting waste to the nearest plain. Thus, the future use of the material should consider mitigation activities to reduce the risks to acceptable levels.

The quality of the study could be improved in cases wherein different scenarios of reuse conditions are known, on which basis there will be changes in physical and chemical properties of the waste. Nevertheless, the current study was successful in providing a methodology that included both the current scenario and the simplest reuse scenario for risk assessment. These risk evaluations for abandoned mine sites may be used as a basis of further research and to determine suitable pathways for the management of EW. This study points towards the crucial issue of coupling risk assessment studies with reuse. All activities should be assessed for the current problems they pose to the environment and for future potential uses of the contamination source. Projects undertaken to increase sustainability at sites should seek to balance and maximize the overall environmental, 
social and economic benefits while removing or reducing impacts to soils, groundwater, and surface water to ensure that human health and environmental health are protected.

\section{Acknowledgements}

This work was completed as part of the REMEDIATE (Improved decision-making in contaminated land site investigation and risk assessment) Marie-Curie Innovation Training Network. The network has received funding from the European Union's Horizon 2020 Programme for research, technological development and demonstration under the grant agreement $n$. 643087. REMEDIATE is coordinated by the QUESTOR Centre at Queen's University Belfast. http://questor.qub.ac.uk/REMEDIATE/.

\section{References}

Akbulut, H., Gürer, C., 2007. Use of aggregates produced from marble quarry waste in asphalt pavements. Build. Env. 42, 1921-1930.

APAT, 2008 - Agenzia per la Protezione dell'Ambiente e per i Servizi Tecnici, Italy,. Criteri metodologici per l'applicazione dell'analisi assoluta di rischio ai siti contaminati (Methodological criteria for the application of the analysis absolute risk analysis to the contaminated sites). (available at http://www.isprambiente.gov.it/files/temi/siti-contaminati02marzo08.pdf accessed on 14.09.2017).

ASTM, E1739-95e1, ASTM International, West Conshohocken, PA, 1995. Standard guide for Risk Based Corrective action applied at petroleum release sites.

ASTM, E2081-00, ASTM International, West Conshohocken, PA, 2015. Standard guide for Risk Based Corrective Action.

Balint, R., Said-Pullicino, D., Ajmone-Marsan, F., 2015. Copper dynamics under alternating redox conditions is influenced by soil properties and contamination source. J. Contam. Hydrol. $173,83-91$.

Balint, R., Nechifor, G., Ajmone-Marsan, F., 2014. Leaching potential of heavy metals from contaminated soils under anoxia. Environ. Sci. : Processes Impacts. 16, 211-219.

Banks, D., Younger, P.L., Arenesen, R., Iversen, E.R. and Banks, S.B. 1997. Mine-water chemistry :the good, the bad and the ugly. Environ. Geol. 32, 3.

Bea, F., Montero, P., 1999. Behaviour of accessory phases and redistribution of Zr, REE, Y, Th and $U$ during metamorphism and partial melting of metapelites in the lower crust: An example from the Kinzigite Formation of Ivrea-Verbano, NW Italy. Geochim. Cosmochim. Acta, 63, 1133-1153.

Béjaoui, I., Kolsi-Benzina, N., Didler, V.S., Munoz, M., 2016. Health risk assessment in calcareous agricultural soils contaminated by metallic mining activity under mediterranean climate. CSAWAC 44, 1261-1427.

Binici, H., Shah, T., Aksogan, O., Kaplan, H., 2008. Durability of concrete made with granite and marble as recycle aggregates. J. Mater. Process. Technol. 208, 299-308. 
Blengini, G.A., Nuss, P., Dewulf, J., Nita, V., Talens Peirò, L., Vidal-Legaz, B., Latunussa, C., Mancini L., Blagoeva, B., Pennington, D., Pellegrini, M., Van Maercke, A., Solar, S., Grohol, M., Ciupagea, C., 2017. EU methodology for critical raw materials assessment: Policy needs and proposed solutions for incremental improvements. Resources Policy. 53, 12-19.

Careddu, N., Siotto, G., Siotto, R., Tilocca, G., 2013. From landfill to water, land and life: the creation of the Centre for stone materials aimed at secondary processing. Resources Policy.38 (2013) 258-265.

Castilhos, Z.C., Rodrigues-Filho, S., Rodrigues, A.P.C., Villas-Bôas, R.C., Siegel, S., Veiga, M.M., and Beinhoff, C., 2006. Mercury contamination in fish from gold mining areas in Indonesia and human health risk assessment. Sci. Total Environ. 368, 320-325.

Coulomb, R., Dietz, S., Godunova, M., Bligaard Nielsen, T., 2015. Critical Minerals Today and in 2030 (OECD Environment Working Papers). Organisation for Economic Cooperation and Development, Paris.

Daniel, D.L., 2015. A Case Study Perspective on Working with ProUCL and a State

Public. Health. 12, 12905-12923.

Danielsen, S. W., Alnæs, L., Azrague, K., Suleng, J., 2017. Handling of quarry waste from schist production at Oppdal, Norway. Geophysical Research Abstracts Vol. 19, EGU2017-77491.

Danielsen S. W., Kuznetsova E., 2015. Resource management and a Best available concept for aggregate sustainability. In: Pr`ikryl, R., To“ro“k, A` ., Go’mez-Heras, M., Miskovsky, K. \& Theodoridou, M. (eds) Sustainable Use of Traditional Geomaterials in Construction Practice. Geological Society, London, Special Publications, 416.

Dino, G.A., Danielsen, S.V., Chiappino, C., Engelsen, C.J., 2017.b. Recycling of rock materials as part of sustainable aggregate production in Norway and Italy. Q. J. Eng. Geol. Hydrogeol.Thematic set: Construction Geomaterials. 50: 412-416.

Dino, G.A., Marian, M., 2015. Treatment and exploitation of waste coming from quarry industries: reuse as aggregate. In: G. Lollino et al. (eds.), Engineering Geology for Society and Territory. Ed. Springer, 5: 89-92.

Dino, G.A., Rossetti, P., Biglia, G., Sapino, M.L., Di Mauro, F., Särkkä, H., Coulon, F., Gomes, D., Parejo-Bravo, L., Zapata Aranda, P., Lorenzo Lopez, A., Lopez, J., Garamvölgyi, E.; Stojanovic S., Pizza A., De La Feld M., 2017.a. SMART GROUND project: a new approach to data accessibility and collection for Raw Materials and Secondary Raw Materials in Europe. Environ. Eng. Manag. J. 16 (8), pp. 11 (in press).

Dino, G.A., Rossetti, P., Biglia, G., Coulon, F., Gomes, D., Wagland, S., Luste, S., Särkkä, H., Ver, C., Delafeld, M., 2016. SMART GROUND Project: SMART Data Collection and Integration Platform to Enhance Availability and Accessibility of Data and Information in the EU Territory on Secondary Raw Materials. Energy Procedia. 97, 15-22. 
Felekoglu, B., 2007. Utilisation of high volumes of limestone quarry wastes in concrete industry (self-compacting concrete case). Resour. Conserv. Recycl. 51, 770-791.

Floreani, A., Zorzet, A., 2016. Stima dell' esposizione e del calcolo del rischio inalatorio nell'analisi di rischio sito specifica: confronto fra diverse linee guida e software.(State of exposure and calculation of inhalation risk in site specific risk analysis: comparison about different guides and software.) Ingegneria dell'Ambiente .3.

Garuti, G., Bea, F., Zaccarini, F. \& Montero, P., 2001. Age, geochemistry and petrogenesis of the ultramafic pipes in the Ivrea Zone, NW Italy. J. Pterol. 42, 433-457.

Gencel, O., Ozel, C., Koksal, F., Erdogmus, E., Martínez-Barrera, G., Brostow, W., 2012. Properties of concrete paving blocks made with waste marble. J. Clean Prod. 21, 62-70.

Gerba, C. P., 2009. Risk Assessment, In Environmental Microbiology (pp. 575-587). Elsevier Inc.

Hebhoub, H., Aoun, H, Belachia, M., Houare, H.and Ghorbel, E., 2011. Use of waste marble aggregates in concrete. Constr. Build. Mater. 25, 1167-1171.

Li, X., and Thornton, I., 2001. Chemical partitioning of trace and major elements in soils contaminated by mining and smelting activities. Appl. Geochem. 16, 1693-1706.

Li, Z., Ma, Z., van der Kuijp, T.J., Yuan, Z., and Huang, L., 2014. A review of soil heavy metal pollution from mines in China: Pollution and health risk assessment. Sci. Total Environ. 468$469,843-853$.

Ličina, V., Akšić, M.F., Tomić, Z., Trajković, I., Antić Mladenović, S., Marjanović, M., and Rinklebe, J. 2017. Bioassessment of heavy metals in the surface soil layer of an opencast mine aimed for its rehabilitation. J. Environ. Manage. 186. 240-252.

Luodes, H., Kauppila, P.M., Luodes, N., Aatos, S., Kallioinen, J., Luukkanen, S., Aalto, J., 2012. Characteristics and the environmental acceptability of the natural stone quarrying waste rocks. Bull. Eng. Geol. Environ. 71, 257-261.

Ministero dell'ambiente e della tutela del territorio,2006. Gazzetta Ufficiale n. 88 of 14 Aprile 2006 Decreto Legislativo 3 aprile 2006, n. 152"Norme in materia ambientale." (Norms concerning the environment.) (http://efficienzaenergetica.acs.enea.it/doc/dlgs_3-406_completo.pdf accessed 14.09.2017)

Rodríguez, L., Ruiz, E., Alonso-Azcárate, J., and Rincón, J., 2009. Heavy metal distribution and chemical speciation in tailings and soils around a $\mathrm{Pb}-\mathrm{Zn}$ mine in Spain. J. Environ. Manage. 90, 1106-1116.

Rossetti, P., Dino, G.A., Biglia, G., Costa, E., 2017. Characterization of secondary raw materials from mine waste: a case study from the Campello Monti $\mathrm{Ni} \pm \mathrm{Cu} \pm \mathrm{Co} \pm \mathrm{PGE}$ mining site (Western Alps, Italy). Proceedings Sardinia 2017 / Sixteenth International Waste Management and Landfill Symposium/ 2 - 6 October 2017S. Margherita di Pula, Cagliari, Italy. (in press) 
U.S. EPA, Washington, DC, 1989. Risk assessment guidance for Superfund (RAGS), Vol. I, Human health evaluation manual (Part A) - Interim final. EPA/540/1-89/002.

U.S. EPA, Washington, DC, 2009. Risk assessment guidance for superfund, in Part A: Human Health Evaluation Manual; Part E, Supplemental Guidance for Dermal Risk Assessment; Part F, Supplemental Guidance for Inhalation Risk Assessment.

U.S. EPA, Washington, DC, 2011. Exposure Factors Handbook 2011 Edition (Final).

Väänänen, K., Kauppila, T., Mäkinen, J., Leppänen, M.T., Lyytikäinen, M., and Akkanen, J., 2016. Ecological risk assessment of boreal sediments affected by metal mining: Metal geochemistry, seasonality, and comparison of several risk assessment methods. Integr. Environ. Assess. Manag. 12, 759-771.

Vidal-Legaz, B., Mancini, L., Blengini, G., Pavel, C., Marmier, A., Blagoeva, D., Latunussa, C., Nuss, P., Dewulf, J., Nita, V., Kayam, Y., Manfredi, S., Magyar, A., Dias, P., Baranzelli, C., Tzimas, E., Pennington, D., 2016. EU Raw Materials Scoreboard 1st ed. Publications Office of the European Union, Luxembourg. G.A.

Yuan, C., Shi, J., He, B., Liu, J., Liang, L., and Jiang, G., 2004. Speciation of heavy metals in marine sediments from the East China Sea by ICP-MS with sequential extraction. Environ. Int. 30, 769-783. 